\title{
OPTIMIZATION OF THE VARIABLE REFRIGERANT FLOW SYSTEMS BY USE OF GENETIC ALGORITHM AND ENERGY, EXERGY, AND ECONOMIC ANALYSIS FOR THREE COOLANT FLUIDS
}

\author{
M.Lotfihejrandoost ${ }^{1}$, A.Behbahani ${ }^{2}$, M.A.Ehyaei ${ }^{*}$
}

\begin{abstract}
The current study aimed at investigation of the Variable Refrigerant Flow (VRF). Energy, exergy, and economic model for R11, R22, and R134a refrigerants. The genetic algorithm was used for optimization of the cycle. The objective functions in the current study were the second law efficiency and cooling cost. The cooling cost was a new economic function that was defined in this paper for the first time. Results showed that the highest Coefficient of Performance (COP) and second law's efficiency as well as the lowest cooling cost and exergy loss belonged to the refrigerant R134a, and second and third to it were R11 and R22. The optimum values of condenser pressure and evaporators 1, 2, and 3 for the refrigerant R134a were 799.7, 706.2, 925.2, and $23122(\mathrm{kPa})$, and the mass discharge of the evaporators 1 and 2, was 0.1 and $0.072(\mathrm{~kg} / \mathrm{s})$.
\end{abstract}

Keywords: Exergy, Evaporator, VRF, COP, Cost

\section{INTRODUCTION}

The systems with VRF were first designed and built about 20 years ago, in Japan. Although today, these systems are being used in many countries, still many experts do not have enough information about this system. These systems were first used in Europe in 1987. It should be noted that nowadays in Japan, $50 \%$ of air conditioning used by the medium commercial buildings (buildings up to $70000 \mathrm{ft}^{2}\left[6500 \mathrm{~m}^{2}\right]$ of the area) and one-third of the large commercial buildings (more than $70000 \mathrm{ft}^{2}\left[6500 \mathrm{~m}^{2}\right]$ of the area) are of this type.

The VRF systems are also, actually a type of channel-less multi-part air conditioning systems which have additional capabilities. The structure of VRF systems are a little more complicated and have the capability of connecting to channel fan coil units. These systems are more complicated than the multi-part air conditioning systems and consist of several compressors and evaporators. Also, their control system is more complicated than that of the multi-part air conditioning systems. The rationale behind naming these systems as the "systems with variable refrigerant flow" of the "VRF" systems is that these systems can control the amount of the refrigerant input from each evaporator. Controlling the input refrigerant from each evaporator is a characteristic specific to VRF systems, by the use of which, a large number of the evaporators with different capacities and structures can be simultaneously used for supplying cooling and heating in different areas, with the capability of independent and regional controlling of the room's internal conditions. In these systems, the recovery of heat from another area is also viable. This characteristic significantly reduces the energy consumption. The VRF systems are modular and have a low weight, as in these systems, each module can be easily carried to the place of mounting, and they can be sent up and down a building through an elevator. Besides, in these systems, by putting some modules together, high cooling capabilities can also be obtained. The structure of VRF systems is such that each module (each dual set of modules) forms an independent and complete refrigeration cycle, but these modules all operate under the command of a central control system. The modularity of these systems also has other capabilities such as step-by-step and region-to-region controlling. For example, if a part of a large building has no residents, the VRF systems such as variable volume can be used for supplying the cooling, only for the parts with residents. The relatively low weight of VRF's enables them to be used without any specific construct constructs and the reinforcements[1,2].

\footnotetext{
${ }^{1}$ Department of Energy system, South Tehran Branch, Islamic Azad University, Tehran, Iran

${ }^{2}$ Department of Mechanical Engineering, K.N.Toosi, University of Technology, Iran

${ }^{3}$ Department of Mechanical Engineering, Pardis Branch, Islamic Azad University, Pardis new city, Iran

${ }^{*}$ E-mail address: aliehyaei@yahoo.comＴel:+98-9123478028

Orcid id: https://orcid.org/0000-0002-0856-1262

Manuscript Received 8 April 2018, Accepted 25 May 2018
} 
There have been a several studies conducted on the VRF systems and applications in residential building. Aynor et al. in 2010, dealt with evaluation and review of the works done in terms of the VRF systems regarding their structure, performance, and application [3]. Kwon et al. in 2014, evaluated the use of a VRF system for an educational unit in the heating mode. The results showed that the system's performance can be improved by the use of a heat exchanger [4]. Zhu et al. in 2014 investigated a VRF system with the enthalpy wheel system to meet the heating load. They showed this system could cover all zones with specified set-point [5]. Meng et al. in 2015 investigated experimentally cooling performance of a VRF system. They employed micro channel heat exchanger. This system has a better performance in heat season [6]. Yu et al. in 2016 investigated a comparative study between VRF and VAV systems in two different climate conditions. The VRF systems consumed 40-53\% less energy rather than VAV systems. This saving energy is depended upon many factors such as operating mode and set point temperature [7].

Kim et al. in 2018 investigated a VRF system with dedicated outdoor system in small office building located in USA. They conclude that by using this system, energy saving is about 78.8 (kWh) or 109\% [8]. Kani-Sanchez in 2017 investigated energy saving of the VRF heat pump systems with heat recovery to meet heating and cooling loads of office building located south western Ontario (Canada). They developed many design optimization methods. They showed that appropriate size of equipment led to $16 \%$ of energy saving [9]. Li et al. in 2017 proposed a new model included the VRF system with split type air condition system. They developed a model for this system. With this system energy losses were reduced. Energy saving values were $12.1 \%, 11.6 \%$ and $11.6 \%$ for a one floor residential building in Beijing, Shanghai and Guangzhou, Respectively [10].

Several papers have been investigated the modeling of the room air conditioner and VRF system. These model were bases on energy analysis and building energy consumption. These models were divided to three groups: steady state, transient and dynamic models [11-13]. Also, several papers have been published about the application of this method in several systems especially power plant and dispersed power generation [14-29].

Reviewing the previous works, it can be concluded that there have been no comprehensive studies conducted on the VRF's energy, exergy, and economic modelling and the effects of different refrigerants such as R11, R22, and R134a. Firstly, the introduction of the VRF system, its components, and the factors effective on its performance, are dealt with. Then, through the mathematical modelling and modeling of the basic cycle of this system, the thermodynamic specifications of the refrigerants R11, R22, and R134a at different points of the cycle were calculated, and the impacts of the factors effective on the cycle's COP were evaluated. After the exergy and economic analysis of the cycle, the VRF system's cycle is optimized by the use of the multi-purpose genetic algorithm. The innovations of the current study are:

- The comprehensive energy, exergy, and economic analysis of the VRF cycle

- Proposing a new method for calculation of the cooling load cost

- Calculation of energy and exergy efficiency, entropy production, and cooling generation costs for the three refrigerants R11, R22, and R134a

- Optimization of the VRF cycle by the multi-purpose genetic algorithm for the three types of refrigerant fluids (R11, R22 and R134a)

- Analysis of the above cycle's sensitivity to its key parameters.

\section{MATHEMATICAL MODELLING OF VRF CYCLE}

Figure 1 shows a schematic diagram of the VRF system. In this figure, the direction of the arrows shows the direction of the refrigerants movement. As it is seen in the figure, the cycle consists of a compressor, a condenser, evaporator, 5 strangle valves, and two separators. In this system, controlling the refrigerant fluid is one of the most important design parameters. The refrigerant flow output from the evaporators 1 and 2, enters the expansion valves to have the same pressure as the evaporator (3), and to maintain the pressure balance at the inlet of the compressor. The refrigerant obtained from the mixing of the three evaporators is collected at point (1), and then, its pressure is increased in the compressor (point 2). In the condenser, the refrigerant gives its energy to the surrounding environment and arrives at the point 3 . In this point, the refrigerant is divided to three pressure levels for the evaporator (1), (2), (3) and enters the three evaporators. The mathematical modelling hypotheses are as follows:

1) The pipes pressure drop has been assumed to be about $3 \%$. 
Journal of Thermal Engineering, Research Article, Vol. 6, No. 3, pp. 381-404, April, 2020

2) The efficiency of the condenser is $85 \%$.

3) The heat dissipation to the environment is ignored.

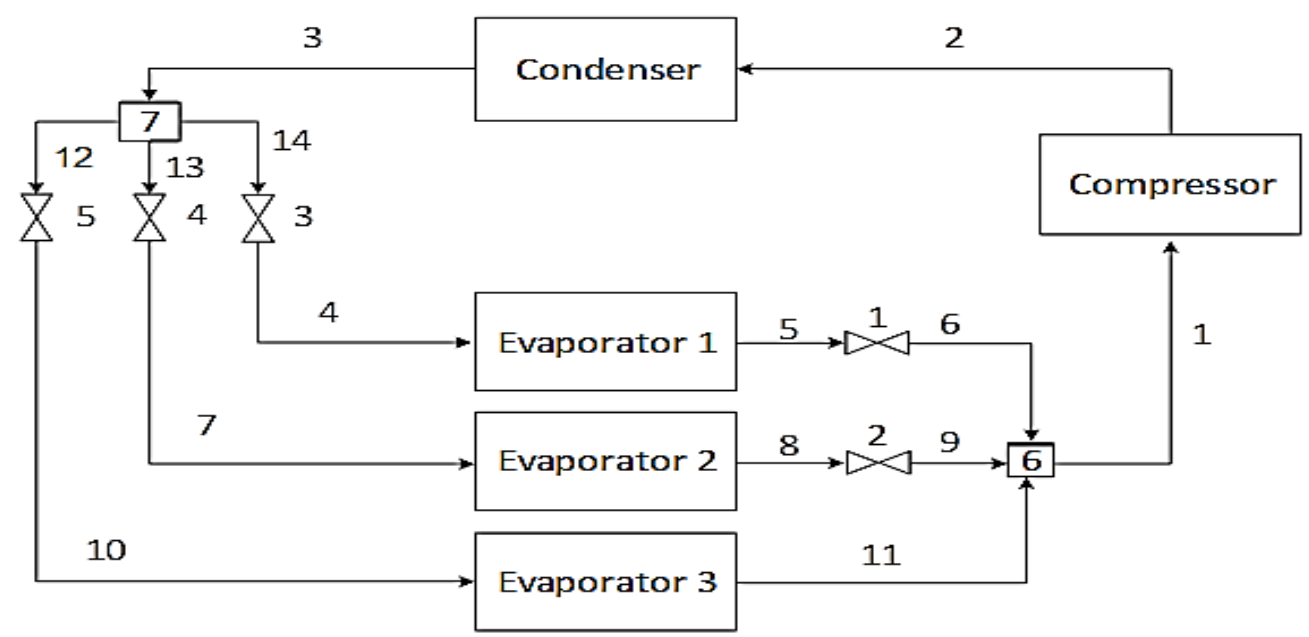

Figure1. A schematic diagram of the VRF system

The heat exchange amount in the evaporators 1,2, and three are calculated as follows [30]:

$$
\begin{gathered}
\dot{Q}_{\text {Evap } 1}=\dot{m}_{4}\left(h_{5}-h_{4}\right) \\
\dot{Q}_{\text {Evap } 2}=\dot{m}_{7}\left(h_{8}-h_{7}\right) \\
\dot{Q}_{\text {Evap } 3}=\dot{m}_{10}\left(h_{11}-h_{10}\right)
\end{gathered}
$$

In which $\dot{\mathrm{Q}}_{\text {Evap1 }}, \dot{\mathrm{Q}}_{\text {Evap2}}, \dot{\mathrm{Q}}_{\mathrm{Evap} 3}$ are the heat exchange rates in the evaporators $9(\mathrm{~kW}), \dot{\mathrm{m}}_{4}, \dot{\mathrm{m}}_{7}, \dot{\mathrm{m}}_{10}$ are the mass discharge of the evaporators 1,2 , and $3(\mathrm{~kg} / \mathrm{s})$, and $\mathrm{h}_{4}, \mathrm{~h}_{5}, \mathrm{~h}_{7}, \mathrm{~h}_{8}, \mathrm{~h}_{10}, \mathrm{~h}_{11}$ are the enthalpies at the marked points $(\mathrm{kJ} / \mathrm{kg})$

The law of conservation of mass for the evaporators 1,2, and 3 are as follows:

$$
\begin{gathered}
\dot{m}_{4}=\dot{m}_{5} \\
\dot{m}_{7}=\dot{m}_{8} \\
\dot{m}_{10}=\dot{m}_{11}
\end{gathered}
$$

In which $\dot{\mathrm{m}}_{5}, \dot{\mathrm{m}}_{8}, \dot{\mathrm{m}}_{10}$ are the mass discharge of the evaporators 1,2 , and $3(\mathrm{~kg} / \mathrm{s})$.

The equations of mass and energy conservation in the mixing chamber are as follows [30]:

$$
\begin{gathered}
\dot{m}_{1}=\dot{m}_{6}+\dot{m}_{9}+\dot{m}_{11} \\
\dot{m}_{1} h_{1}=\dot{m}_{6} h_{6}+\dot{m}_{9} h_{9}+\dot{m}_{11} h_{11}
\end{gathered}
$$


In which $\mathrm{m}_{6}, \dot{\mathrm{m}}_{9}$ are mass discharge after the strangulation valve, $\dot{\mathrm{m}}_{11}$ is the mass discharge after evaporator $3, \dot{\mathrm{m}}_{1}$ is the mass discharge of the compressor $9(\mathrm{~kg} / \mathrm{s})$, and $\mathrm{h}_{1}, \mathrm{~h}_{9}, \mathrm{~h}_{6}, \mathrm{~h}_{11}$ are the enthalpies at different points of the cycle $(\mathrm{kJ} / \mathrm{kg})$.

The work needed for the compressor can be calculated as follows [30]:

$$
w_{\text {Comp }}=\dot{m}_{1}\left(h_{1}-h_{2}\right) \dot{m}_{1}=\dot{W}_{\text {Comp }}
$$

In the above equation, $\mathrm{m}_{-}{ }_{-} 1$ is the mass discharge of the compressor $(\mathrm{kg} / \mathrm{s})$, WComp and $\mathrm{h} 2$ are the compressor output and input enthalpy $(\mathrm{kJ} / \mathrm{kg})$.

The heat exchange between the condenser and environment can be calculated by the following equation [30]:

$$
\dot{Q}_{\text {cond }}=\dot{m}_{2}\left(h_{3}-h_{2}\right)
$$

In the above equation, $\dot{m}_{2}$ is the mass discharge passing through the condenser $(\mathrm{kg} / \mathrm{s})$, and $\mathrm{h}_{2}$ and $\mathrm{h}_{3}$ are the enthalpies of the points 2 and $3(\mathrm{~kJ} / \mathrm{kg})$. The laws of conservation of mass and energy for separation are as follows [30]:

$$
\begin{gathered}
\dot{m}_{14}+\dot{m}_{13}=\dot{m}_{12}+\dot{m}_{3} \\
\dot{m}_{14} h_{14}+\dot{m}_{13} h_{13}=\dot{m}_{12} h_{12}+\dot{m}_{3} h_{3}
\end{gathered}
$$

For exergy analysis, potential exergy, kinetic exergy, and chemical exergy components have been ignored in all processes.

The flow's exergy is equal to the equation 1 [30]:

$$
\Psi=\left(h-T_{0 s}+\frac{1}{2} V^{2}+g z\right)-\left(h_{0}-T_{0 s}+g z_{0}\right)
$$

By ignoring the kinetic and potential exergy, the equation will be as follows [30]:

$$
\Psi=\left(h-h_{0}\right)-T_{0}\left(s-s_{0}\right)
$$

In which $\mathrm{h}$ and $\mathrm{S}$ are the enthalpy and entropy, and $\mathrm{h}_{0}$ and $\mathrm{s}_{0}$ are the thermodynamic specifications in the reference mode $(\mathrm{kJ} / \mathrm{kgK})$. Since the condenser is in the ambient temperature, $\mathrm{V}$ is the fluid's speed (m/s), $\mathrm{g}$ is the gravity velocity $\left(\mathrm{m} / \mathrm{s}^{2}\right)$, and $\mathrm{z}$ is the reference height $(\mathrm{m})$. The condenser's temperature is considered to be equal to the reference temperature $\left(40^{\circ} \mathrm{C}\right)$.

Usually, the irreversibility is defined as the difference between the reversible work and actual work. If we want to write this definition in general terms and the form of the intensity equations, taking into account more than one mass and more than one heat transfer, we will have [30]:

$$
\dot{I}_{c v}=\left(\sum \dot{m}_{i} \Psi_{i}-\sum \dot{m}_{e} \Psi_{e}\right)+\sum\left(1-\frac{T_{0}}{T_{j}}\right) \dot{Q}_{c v j}-\dot{W}_{c v}
$$

$\dot{\mathrm{I}}_{\mathrm{w}}$ is the reversibility $(\mathrm{kW}), \dot{\mathrm{m}}_{\mathrm{c}}$ and $\dot{\mathrm{m}}_{\mathrm{e}}$ are the input and output mass discharges $(\mathrm{kg} / \mathrm{s}), \Psi_{\mathrm{e}}$ and $\Psi_{\mathrm{i}}$ are the input and output flow exergies $(\mathrm{kJ} / \mathrm{kg}), \mathrm{T}_{\mathrm{j}}$ is the reference temperature $(\mathrm{kW}), \dot{\mathrm{Q}}_{\mathrm{cvj}}$ is the heat exchange $(\mathrm{kW})$, and $\dot{\mathrm{W}}_{\mathrm{cv}}$ is the amount of work production of the control volume $(\mathrm{kW})$.

The irreversibility rate for the compressor is as equation (16) [30]: 
Journal of Thermal Engineering, Research Article, Vol. 6, No. 3, pp. 381-404, April, 2020

$$
\dot{I}_{\text {Comp }}=\dot{m}_{1}\left(\Psi_{1}-\Psi_{2}\right)+\dot{W}_{\text {Comp }}
$$

$\Psi_{1}$ and $\Psi_{2}$ are the rates of energy before and after compressor $(\mathrm{kJ} / \mathrm{kg})$.

The irreversibility in the condenser, regarding cooling it by the ambient weather which is in the reference temperature, is as follows [30]:

$$
\dot{\mathrm{I}}_{\text {Cond }}+\dot{\mathrm{m}}_{\text {Cond }}\left(\Psi_{1}-\Psi_{2}\right)=\dot{\mathrm{m}}_{1}-\left(\Psi_{2}-\Psi_{3}\right)+\left(1-\frac{\mathrm{T} .}{\mathrm{T}_{\text {Cond }}}\right)-\dot{\mathrm{Q}}_{\text {cond }}
$$

$\Psi_{3}$ is the exergy rate after condenser $(\mathrm{kJ} / \mathrm{kg})$.

The evaporator irreversibility, regarding the heat exchange in an environment other than reference environment, is as follows [30]:

$$
\dot{\mathrm{I}}_{\text {Evap }}=\dot{\mathrm{m}}_{\text {Evap }}\left(\Psi_{\mathrm{i}}-\Psi_{\mathrm{e}}\right)+\left(1-\frac{\mathrm{T} .}{\mathrm{T}_{\text {Evap }}}\right)-\dot{\mathrm{Q}}_{\text {Evap }}
$$

Which is as follows for the evaporators 1,2 , and 3 [30]:

$$
\begin{gathered}
\dot{I}_{\text {Evap } 1}=\dot{m}_{4}\left(\Psi_{4}-\Psi_{5}\right)+\left(1-\frac{T .}{T_{\text {Evap } 1}}\right) \dot{Q}_{\text {Evap } 1} \\
\dot{I}_{\text {Evap } 2}=\dot{m}_{7}\left(\Psi_{7}-\Psi_{8}\right)+\left(1-\frac{T .}{T_{\text {Evap } 2}}\right) \dot{Q}_{\text {Evap } 2} \\
\dot{I}_{\text {Evap } 3}=\dot{m}_{10}\left(\Psi_{10}-\Psi_{11}\right)+\left(1-\frac{T .}{T_{\text {Evap } 3}}\right) \dot{Q}_{\text {Evap } 3}
\end{gathered}
$$

In the above equation, $\Psi_{7}, \Psi_{10}, \Psi_{11}, \Psi_{8}, \Psi_{5}, \Psi_{4}$ are the input and output exergies of the evaporators 1,2 , and $3(\mathrm{~kJ} / \mathrm{kg})$.

Since there is no heat exchange and work in the strangulation process, the energy loss is as follows [30]:

$$
\dot{\mathrm{I}}_{\mathrm{Exp}}=\dot{\mathrm{m}}_{\mathrm{Exp}}\left(\Psi_{\mathrm{i}}-\Psi_{\mathrm{e}}\right)
$$

Which is as follow for the strangulation valves $1,2,3,4$, and 5 [30]:

$$
\begin{gathered}
\dot{\mathrm{I}}_{\mathrm{Exp} 1}=\dot{\mathrm{m}}_{5}\left(\Psi_{5}-\Psi_{6}\right) \\
\dot{\mathrm{I}}_{\mathrm{Exp} 2}=\dot{\mathrm{m}}_{6}\left(\Psi_{8}-\Psi_{9}\right) \\
\dot{\mathrm{I}}_{\mathrm{Exp} 3}=\dot{\mathrm{m}}_{14}\left(\Psi_{14}-\Psi_{4}\right)
\end{gathered}
$$




$$
\begin{aligned}
& \dot{\mathrm{I}}_{\mathrm{Exp} 4}=\dot{\mathrm{m}}_{13}\left(\Psi_{13}-\Psi_{7}\right) \\
& \dot{\mathrm{I}}_{\mathrm{Exp} 5}=\dot{\mathrm{m}}_{12}\left(\Psi_{12}-\Psi_{10}\right)
\end{aligned}
$$

Since like strangulation valve, there is no heat exchange and work in the divider, the exergy loss is as follows [30]:

$$
\dot{\mathrm{I}}_{\mathrm{Sep}}=\left(\sum \dot{\mathrm{m}}_{\mathrm{i}} \Psi_{\mathrm{i}}-\sum \dot{\mathrm{m}}_{\mathrm{e}} \Psi_{\mathrm{e}}\right)
$$

For dividers 6 and 7, the exergy loss is as follows [30]:

$$
\begin{gathered}
\dot{\mathrm{I}}_{\mathrm{Sep}, 6}=\dot{\mathrm{m}}_{6} \psi_{6}+\dot{\mathrm{m}}_{9} \psi_{9}+\dot{\mathrm{m}}_{11} \psi_{11}-\dot{\mathrm{m}}_{1} \psi_{1} \\
\dot{\mathrm{I}}_{\text {Sep }, 7}=\dot{\mathrm{m}}_{3} \psi_{3}-\dot{\mathrm{m}}_{12} \psi_{12}-\dot{\mathrm{m}}_{13} \psi_{13}-\dot{\mathrm{m}}_{14} \psi_{14}
\end{gathered}
$$

The total irreversibility (exergy loss) is as follows [30]:

$$
\dot{\mathrm{I}}_{\text {Total }}=\sum_{\mathrm{i}} \dot{\mathrm{I}}_{\mathrm{i}}=\dot{\mathrm{I}}_{\text {Comp }}+\dot{\mathrm{I}}_{\text {Sep }}+\dot{\mathrm{I}}_{\text {Exp }}+\dot{\mathrm{I}}_{\text {Evap }}+\dot{\mathrm{I}}_{\text {Cond }}
$$

The machine's COP can be calculated as follows [30]:

$$
C O P=\frac{\dot{Q}_{E v a p 1}+\dot{Q}_{E v a p 2}+\dot{Q}_{E v a p 3}}{\dot{W}_{C o m p}}
$$

The exergy efficiency or the efficiency of the second law of thermodynamic is as follows [30]:

$$
\text { Exergy efficiency }=1-\frac{\sum_{\mathrm{i}} \dot{\mathrm{I}}_{1}}{\dot{\mathrm{W}}_{\mathrm{Comp}}}
$$

In the refrigeration cycle, the exergy input from the outside of the system is only the electrical energy of compressor. Therefore, the cost of the exergy from outside of the system is the very cost of the electrical energy unit, and the initial investment costs include the costs of the compressor, heat exchangers, expansion valves, strangulation valve, electric motor, and the dividers. The costs of the dividers have been ignored. The product of the system is also just the cooling capacity. The objective function for calculation of the cooling produced by the VRF system is as follows [31-33]:

$$
C_{Q}=C_{1}+C_{o}+C_{E}
$$

In the above equation, $C_{Q}$ is the cooling costs $(\$ / \mathrm{kWh}), C_{1}$ is the initial mounting costs $(\$ / \mathrm{kWh}), C_{o}$ is maintenance costs $(\$ / \mathrm{kWh})$, and $C_{E}$ is the cost of the electricity consumed $(\$ / \mathrm{kWh})$. The advantage of this proposed method is the calculation of the costs per each kilowatt of the produced electricity. Besides, by changing the parameters and conditions, the final cost of the produced cooling can be calculate 
Journal of Thermal Engineering, Research Article, Vol. 6, No. 3, pp. 381-404, April, 2020

The cooling costs about the initial mounting costs can be calculated as follows [31-33]:

$$
C_{I}=\frac{C I}{8760 C O P W_{\text {comp }}}
$$

In which $\mathrm{C}$ is initial mounting costs (\$), and I is the initial costs profit.

The initial costs profit can be calculated as follows [31-33]:

$$
I=\frac{i(1+i)^{L}}{(1+i)^{L}-1}
$$

In the above equation, $\mathrm{L}$ is the equipment lifespan (Year), and $\mathrm{i}$ is the interest rate. The maintenance costs are considered to be $4 \%$ of the initial mounting costs. The costs of electricity can be calculated as follows [31-33]:

$$
C_{Q}=\frac{\text { Electricity cost }(U S \$ / k W h)}{C O P}
$$

The electricity cost has been considered to be $0.071(\mathrm{US} \$ / \mathrm{kWh})$ [31-33].

The initial costs of the compressor can be calculated as follows [34]:

$$
C_{\text {Comp }}=a_{\text {Comp }} k_{1} \frac{V_{1}}{0.9-\eta_{\text {Comp }}} \frac{P_{2}}{P_{1}} \ln \frac{P_{2}}{P_{1}} \cdot \frac{P_{2}}{P_{1}}
$$

In which, $\mathrm{k}_{1}$ is the refrigerant costs per volume $\mathrm{V}_{1}, \frac{\mathrm{P}_{2}}{\mathrm{P}_{1}}$ is the compressor pressure ratio, and $\eta_{\text {Comp }}$ is the isentropic efficiency of the compressor. The compressor efficiency has been considered to be $70 \%$. For calculation of the $\mathrm{a}_{\text {Comp }}$ and $\mathrm{k}_{1}$, the following equations can be used [47]:

$$
a_{\text {Comp }}=15.84, \quad k_{1}=51.4
$$

The initial costs of the condenser can be calculated as follows [34]:

$$
C_{\text {Cond }}=a_{\text {Cond }} k_{2} \dot{m}_{1} \sqrt{\frac{\eta_{\text {Cond }}}{1-\eta_{\text {Cond }}}}
$$

Therefore, the $\mathrm{a}_{\text {Comp }}$ and $\mathrm{k}_{1}$ coefficients for the condenser are as follows [34]:

$$
a_{\text {Cond }}=29.58, \quad k_{2}=19.65
$$

The $\mathrm{a}_{\mathrm{Eva}}$ and $\mathrm{k}$ coefficients for the evaporator are as follows [34]:

$$
a_{\text {Eva }}=33.29, \quad k_{3}=17.46
$$

The strangulation valve costs are as follows [34]: 


$$
\dot{m}_{E x p} k_{4} C_{E x p}=a_{E x p}
$$

In which, $\mathrm{k}_{4}$ is the cost per mass discharge of the refrigerant $\dot{\mathrm{m}}_{\mathrm{Exp}}(\mathrm{kg} / \mathrm{sec})$.

The coefficients $\mathrm{a}_{\operatorname{Exp}}$ and $\mathrm{k}_{4}$ for the strangulation valve are as follows [34]:

$$
a_{E x p}=29, \quad k_{4}=5.14
$$

The electric motor costs are as the equation 45 [34]:

$$
C_{\text {Elec }}=a_{\text {Elec }} k_{5} P \frac{\eta_{\text {Elec }}}{1-\eta_{\text {Elec }}}
$$

In the above equation, $P$ is the electric motor power $(\mathrm{kW})$, and $\eta_{\text {Elec }}$ is the efficiency of the electric motor. $\mathrm{k}_{5}$ and $\mathrm{a}_{\text {Elec }}$ are the costs per power unit, which can be calculated as follows [34]:

$$
a_{\text {Elec }}=4.84 \quad k_{5}=2.4
$$

\section{GENETIC ALGORITHM}

This algorithm is a random method, based on the genetics and natural evolution processes, for responding to the complicated problems of optimization. It was first created by professor Holland, based on the random global search inspired by natural structures. The most important points in each numerical algorithm are: 1- Generalizability, 2Convergence speed, and 3- Accuracy of the answer. In the genetic algorithm, the first item is desirable, however the items 2 and 3 are contrary, and improvement of one of them leads to the drop in the other. The genetic algorithm is initiated with a primary population, which is totally randomly chosen, and starts a global search. The population size depends on the specifications of the problem. In this algorithm, the genetics terms are used as key definitions. Each strand of the population is like a chromosome, and each binary section (bit) of each strand is like a gene. The strands are the updated values of the design identifiers. From the evolution of the initial population, a new population is created based on the following factors [35]:

1- $\quad$ Reproduction

2- $\quad$ Crossover

3- Mutation

In the reproduction phase, the best chromosomes of the previous iteration have higher chances for being in the next iteration. In the crossover phase, some of the genes of the two select chromosomes replace each other. In the mutation, a series of genes are randomly chosen and changed into other genes through the number associated with mutation. One of the most important parameters in convergence speed and the algorithm precision is the mutation. Without mutation, the convergence speed is high, however, the precision of the answer is low. On the other hand, if the mutation is applied, the answer precision will be highly desirable, however, the number of repetitions for achieving an answer will be high. The most important stage in genetic algorithm is determination of the objective function. This function should be defined in a way to satisfy the optimization conditions of the problem. At the end of optimization by this algorithm, a chromosome is selected as the best chromosome, which is the most desirable response to the problem. Figure 2 shows the flowchart showing how the genetic algorithm works [35]. 


\section{RESULTS AND DISCUSSION}

Figure 2. Genetic algorithm flowchart

The VRF cycle designing conditions are shown in table 1 . The thermodynamic specifications of the three fluids R11, R22, and R134a are shown in table 2. In tables 3 to 5, the thermodynamic specifications of different points in the VRF cycle for the refrigerants R11, R22, and R134a are presented.

Table 1. The VRF cycle designing conditions

\begin{tabular}{|c|c|}
\hline $\mathrm{P}_{2}$ & $2416(\mathrm{kPa})$ \\
\hline $\mathrm{P}_{4}$ & $904.2(\mathrm{kPa})$ \\
\hline $\mathrm{P}_{7}$ & $797.8(\mathrm{kPa})$ \\
\hline $\mathrm{P}_{10}$ & $701.2(\mathrm{kPa})$ \\
\hline$\dot{m}_{4}$ & $0.07662(\mathrm{~kg} / \mathrm{s})$ \\
\hline$\dot{m}_{7}$ & $0.07717(\mathrm{~kg} / \mathrm{s})$ \\
\hline$\dot{m}_{10}$ & $0.07777(\mathrm{~kg} / \mathrm{s})$ \\
\hline$\eta_{\text {Com }}$ & $\% 70$ \\
\hline
\end{tabular}

Table 2. The thermodynamic specifications of the three fluids R11, R22, and R134a

\begin{tabular}{|c|c|c|c|c|}
\hline Coolant & $\begin{array}{c}\text { molar mass } \\
\left(\frac{\mathbf{k g}}{\mathbf{k ~ m o l}}\right)\end{array}$ & $\mathbf{T}_{\mathbf{c}}(\mathbf{K})$ & $\mathbf{P}_{\mathbf{c}}(\mathbf{M P a})$ & $\boldsymbol{\rho}_{\mathbf{c}}\left(\frac{\mathbf{k g}}{\mathbf{m}^{3}}\right)$ \\
\hline $\mathrm{R} 11$ & 137.37 & 47.11 & 4.41 & 554 \\
\hline $\mathrm{R} 22$ & 86.47 & 369.29 & 4.99 & 523.8 \\
\hline $\mathrm{R} 134 \mathrm{a}$ & 102.03 & 374.15 & 4.06 & 511.9 \\
\hline
\end{tabular}


Journal of Thermal Engineering, Research Article, Vol. 6, No. 3, pp. 381-404, April, 2020

Table 3. The thermodynamic specifications of different points in the VRF cycle for the refrigerants R11

\begin{tabular}{|c|c|c|c|c|c|c|}
\hline & $\mathbf{P}(\mathbf{k P a})$ & $\mathbf{T}(\mathbf{K})$ & $\dot{\mathbf{m}}(\mathbf{k g} / \mathbf{s})$ & $\mathbf{h}(\mathbf{J} / \mathbf{k g})$ & $\mathbf{s}(\mathbf{J} / \mathbf{k g K})$ & $\boldsymbol{\Psi}(\mathbf{J} / \mathbf{k g})$ \\
\hline $\mathbf{1}$ & 701.2 & 369.2 & 0.2316 & 437900 & 1683.4 & 35861 \\
\hline $\mathbf{2}$ & 2416 & 460.6 & 0.2316 & 483920 & 1733.9 & 66819 \\
\hline $\mathbf{3}$ & 2416 & 460.6 & 0.2316 & 252820 & 1434.2 & 26073 \\
\hline $\mathbf{4}$ & 904.2 & 377.5 & 0.07662 & 295880 & 1294.2 & 9869.8 \\
\hline $\mathbf{5}$ & 904.2 & 377.5 & 0.07662 & 440390 & 1677 & 40260 \\
\hline $\mathbf{6}$ & 701.2 & 372.7 & 0.07662 & 440390 & 1690.1 & 26349 \\
\hline $\mathbf{7}$ & 797.8 & 371.7 & 0.07717 & 290020 & 1278.8 & 8608.8 \\
\hline $\mathbf{8}$ & 797.8 & 371.7 & 0.07717 & 437940 & 1676.8 & 37863 \\
\hline $\mathbf{9}$ & 701.2 & 369.3 & 0.07717 & 437940 & 1683.5 & 35869 \\
\hline $\mathbf{1 0}$ & 701.2 & 365.8 & 0.07777 & 284260 & 1263.4 & 7444.5 \\
\hline $\mathbf{1 1}$ & 701.2 & 365.8 & 0.07777 & 435420 & 1676.6 & 35392 \\
\hline $\mathbf{1 2}$ & 2416 & 365.6 & 0.07662 & 284260 & 1259.8 & 8517.3 \\
\hline $\mathbf{1 3}$ & 2416 & 371.5 & 0.07717 & 290020 & 1275.4 & 8618.8 \\
\hline $\mathbf{1 4}$ & 2416 & 377.5 & 0.07777 & 295880 & 1291 & 10812 \\
\hline
\end{tabular}

Table 4. The thermodynamic specifications of different points in the VRF cycle for the refrigerants R22

\begin{tabular}{|c|c|c|c|c|c|c|}
\hline & $\mathbf{P}(\mathbf{k P a})$ & $\mathbf{T}(\mathbf{K})$ & $\dot{\mathbf{m}}(\mathbf{k g} / \mathbf{s})$ & $\mathbf{h}(\mathbf{J} / \mathbf{k g})$ & $\mathbf{s}(\mathbf{J} / \mathbf{k g K})$ & $\boldsymbol{\Psi}(\mathbf{J} / \mathbf{k g})$ \\
\hline $\mathbf{1}$ & 701.2 & 285.9 & 0.2316 & 410240 & 1740.3 & 53075 \\
\hline $\mathbf{2}$ & 2416 & 374.2 & 0.2316 & 460410 & 1792.5 & 87678 \\
\hline $\mathbf{3}$ & 2416 & 374.2 & 0.2316 & 277290 & 1249.5 & 66435 \\
\hline $\mathbf{4}$ & 904.2 & 292.9 & 0.07662 & 223770 & 1082.9 & 62616 \\
\hline $\mathbf{5}$ & 904.2 & 292.9 & 0.07662 & 411590 & 1724 & 59263 \\
\hline $\mathbf{6}$ & 701.2 & 287.6 & 0.07662 & 411590 & 1745 & 53022 \\
\hline $\mathbf{7}$ & 797.8 & 288.5 & 0.07717 & 218370 & 1064.6 & 62665 \\
\hline $\mathbf{8}$ & 797.8 & 288.5 & 0.07717 & 410280 & 1729.7 & 56259 \\
\hline $\mathbf{9}$ & 701.2 & 285.9 & 0.07717 & 410280 & 1740.4 & 53074 \\
\hline $\mathbf{1 0}$ & 701.2 & 284.1 & 0.07777 & 213050 & 1064.2 & 62803 \\
\hline $\mathbf{1 1}$ & 701.2 & 284.1 & 0.07777 & 408880 & 1735.5 & 53138 \\
\hline $\mathbf{1 2}$ & 2416 & 283.9 & 0.07662 & 213050 & 1041.4 & 64264 \\
\hline $\mathbf{1 3}$ & 2416 & 288.4 & 0.07717 & 218370 & 1060 & 64023 \\
\hline $\mathbf{1 4}$ & 2416 & 292.8 & 0.07777 & 223770 & 1078.6 & 63883 \\
\hline
\end{tabular}


Journal of Thermal Engineering, Research Article, Vol. 6, No. 3, pp. 381-404, April, 2020

Table 5. The thermodynamic specifications of different points in the VRF cycle for the refrigerants R134a

\begin{tabular}{|c|c|c|c|c|c|c|}
\hline & $\mathbf{P}(\mathbf{k P a})$ & $\mathbf{T}(\mathbf{K})$ & $\mathbf{m}(\mathbf{k g} / \mathbf{s})$ & $\mathbf{h}(\mathbf{J} / \mathbf{k g})$ & $\mathbf{s}(\mathbf{J} / \mathbf{k g K})$ & $\boldsymbol{\Psi}(\mathbf{J} / \mathbf{k g})$ \\
\hline $\mathbf{1}$ & 701.2 & 302.0 & 0.2316 & 415370 & 1722.7 & 43884 \\
\hline $\mathbf{2}$ & 2416 & 369.6 & 0.2316 & 459370 & 1774.4 & 72472 \\
\hline $\mathbf{3}$ & 2416 & 369.6 & 0.2316 & 314940 & 1363.1 & 50683 \\
\hline $\mathbf{4}$ & 904.2 & 308.8 & 0.07662 & 250030 & 1170.3 & 43257 \\
\hline $\mathbf{5}$ & 904.2 & 308.8 & 0.07662 & 417510 & 1712.5 & 49056 \\
\hline $\mathbf{6}$ & 701.2 & 304.1 & 0.07662 & 417510 & 1729.8 & 43918 \\
\hline $\mathbf{7}$ & 797.8 & 304.4 & 0.07717 & 243510 & 1149.3 & 42988 \\
\hline $\mathbf{8}$ & 797.8 & 304.4 & 0.07717 & 415410 & 1714.1 & 46507 \\
\hline $\mathbf{9}$ & 701.2 & 302.0 & 0.07717 & 415410 & 1722.9 & 43884 \\
\hline $\mathbf{1 0}$ & 701.2 & 299.9 & 0.07777 & 237080 & 1128.3 & 42823 \\
\hline $\mathbf{1 1}$ & 701.2 & 299.9 & 0.07777 & 413230 & 1715.6 & 43864 \\
\hline $\mathbf{1 2}$ & 2416 & 299.9 & 0.07662 & 237080 & 1123.5 & 44238 \\
\hline $\mathbf{1 3}$ & 2416 & 304.4 & 0.07717 & 243510 & 1144.8 & 44323 \\
\hline $\mathbf{1 4}$ & 2416 & 308.9 & 0.07777 & 250030 & 1166.1 & 44504 \\
\hline
\end{tabular}

Figure 3 shows the VRF equipment's COP for the three refrigerants R11, R22, and R134a. By changing the refrigerant from R11 to R22 and R134a, the COP of the equipment is increased from 3.2 to 3.8, and 3.6, respectively.

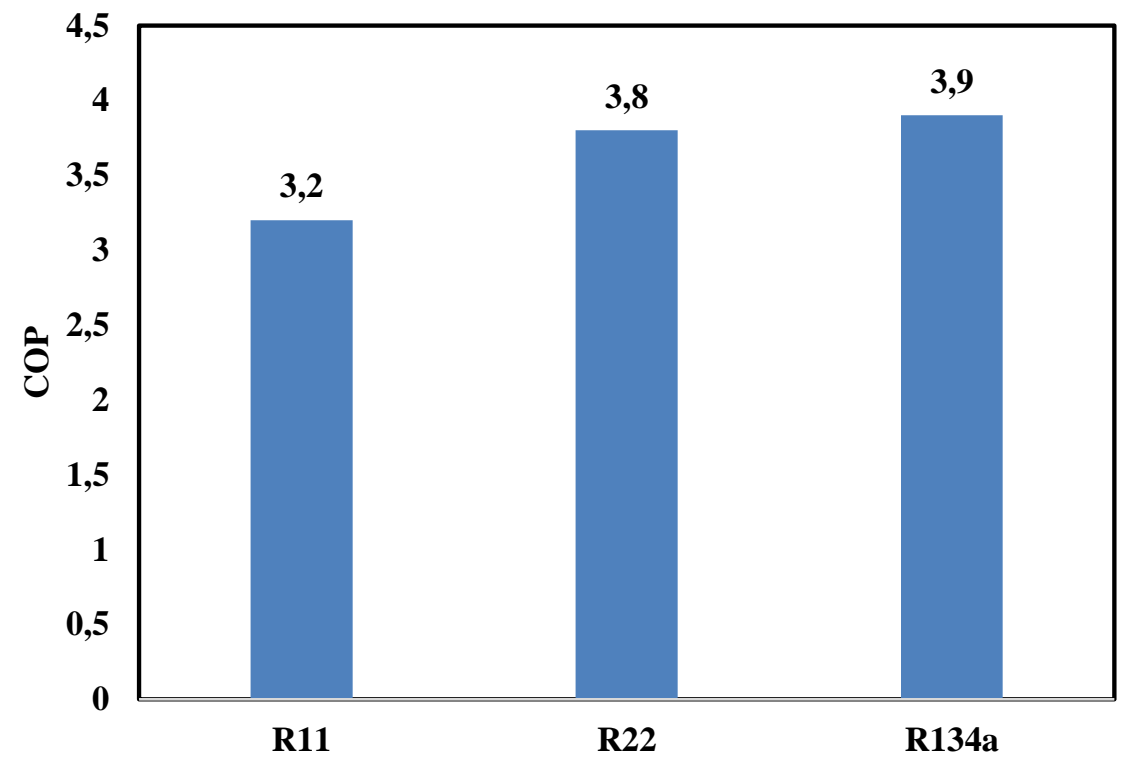

Figure 3. The VRF equipment's COP for the three refrigerants R11, R22, and R134a

Figure 4 shows the efficiency of the second law of thermodynamics of VRF equipment for the three refrigerants R11, R22, and R134a. It is clear from the figure that by changing the refrigerant from R11 to R22 and R134a, the efficiency of the second law of thermodynamics for the VRF cycle is increased from $11 \%$ to $19.1 \%$ and $23.8 \%$, respectively. Figure 5 sows the value of VRF cycle per refrigerants R11, R22, and R134a. By changing the 
refrigerant from R11 to R22 and R134a, the exergy loss is decreased. This change is more evident in changing the refrigerant from R22 to R134a. Figure 6 shows the cost of the cooling produced by the VRF cycle per refrigerants R11, $\mathrm{R} 22$, and R134a. By changing the refrigerant from R11 to R134a, the costs of the produced cooling is decreased.

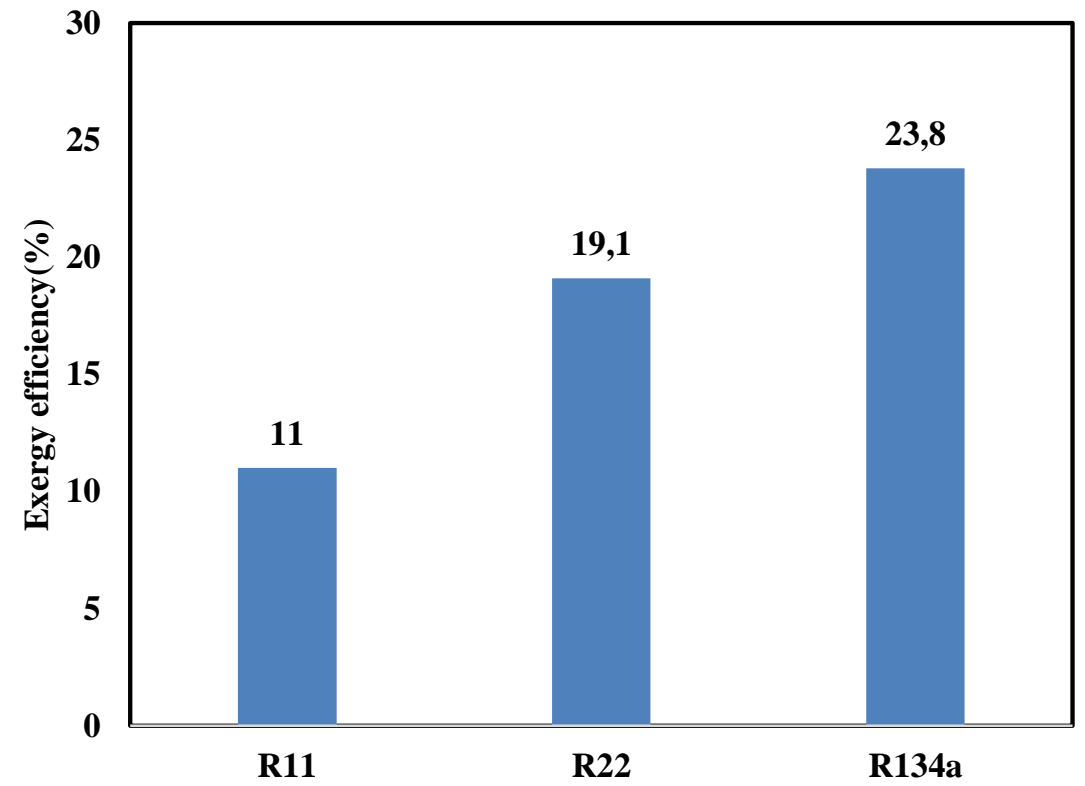

Figure 4. The efficiency of the second law of thermodynamics of VRF equipment for the three refrigerants R11, R22, and R134a

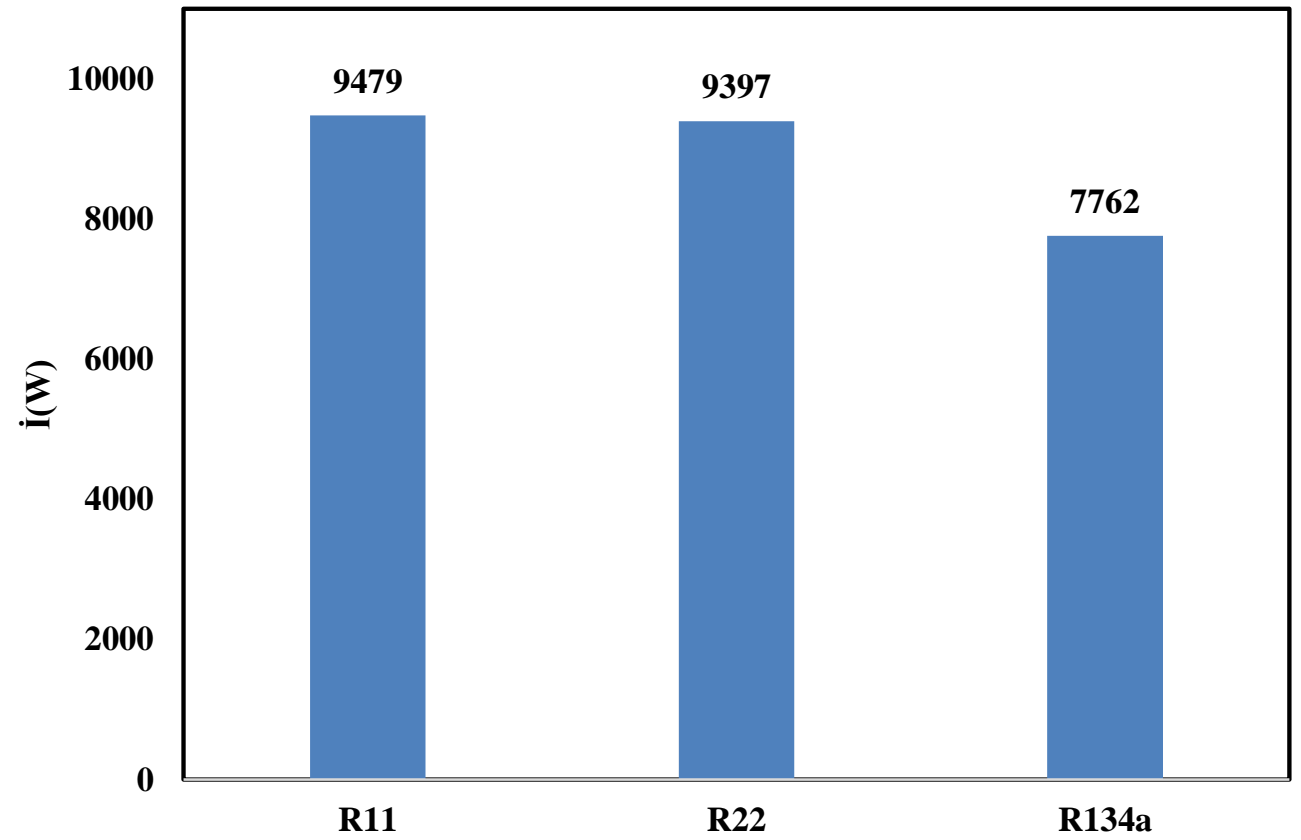

Figure 5. The exergy loss of the VRF cycle per the tree refrigerants R11, R22, and R134a 


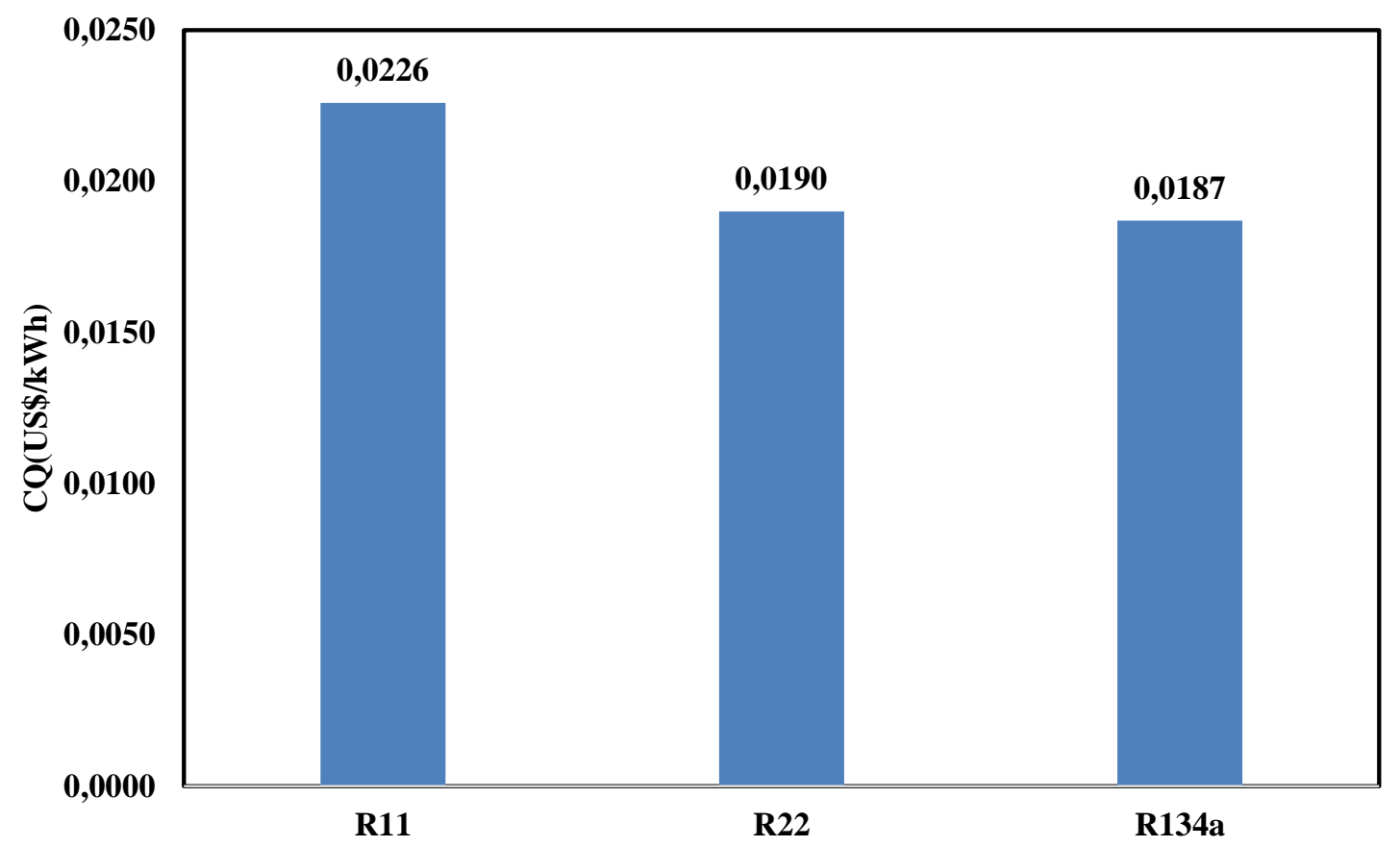

Figure 6. The cost of the cooling produced by the VRF cycle per refrigerants R11, R22, and R134a

Figure 7 shows the exergy loss in different components of the VRF equipment for the refrigerant R11. The lowest exergy loss belongs to the mixture6, and the strangulation valves 3,4 , and 5 after it. The highest exergy loss belongs to the condenser, mixture 6, and evaporators 1,2, and 3, respectively. Figure 8 shows the exergy loss in different components of VRF equipment for the refrigerant R22. The highest exergy loss, like the R11, belongs to the condenser. The lowest exergy loss also belongs to the mixture6. The exergy loss in different components of the VRF equipment for R22 is lower than R11. Figure 9 shows the exergy loss in different components of the VRF equipment for R134a. Like the previous refrigerant, the highest exergy loss belongs to the condenser, and the lowest loss belongs to the Mixture6.

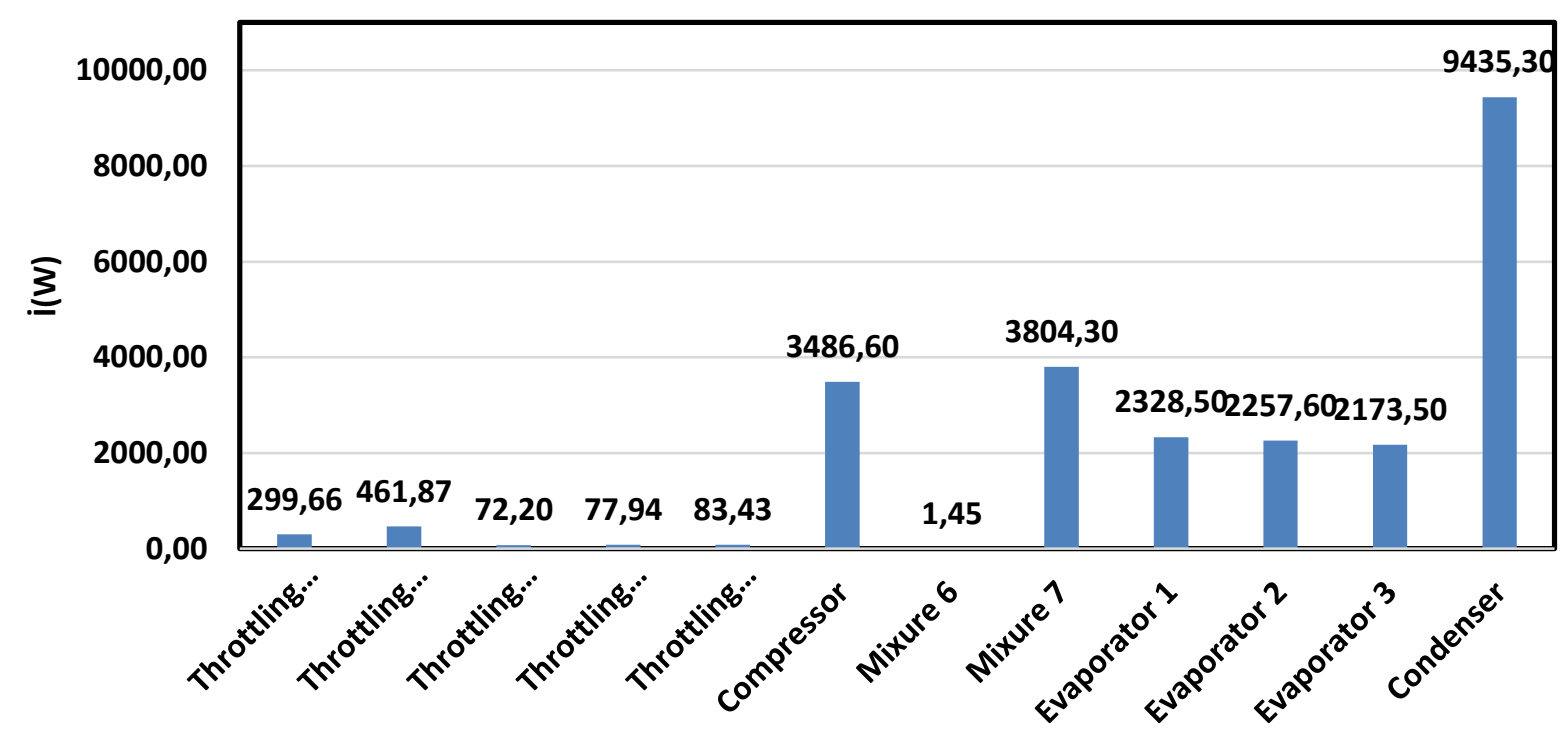

Figure 7. The exergy loss in different components of the VRF equipment for the refrigerant R11 


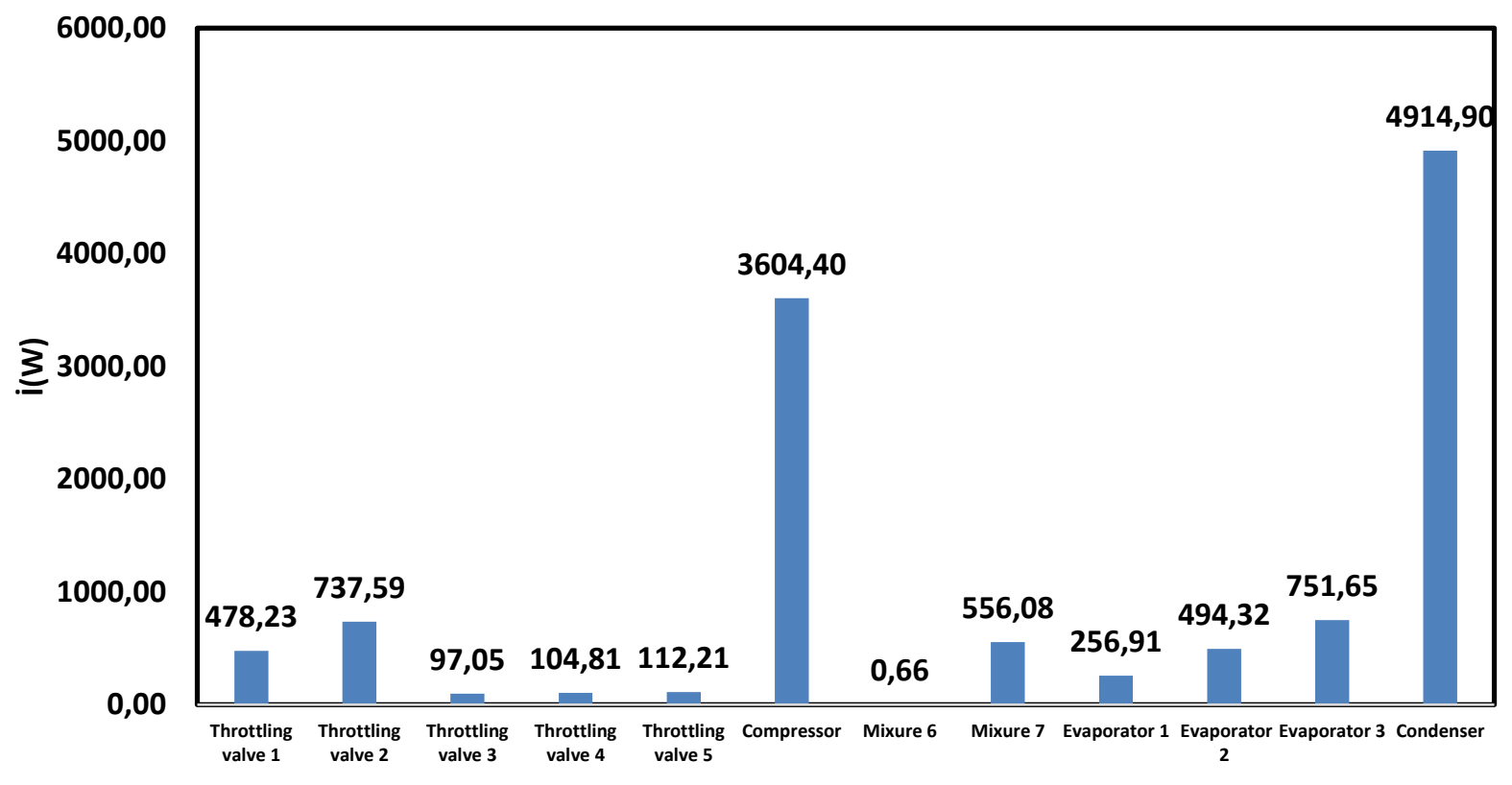

Figure 8. The exergy loss in different components of the VRF equipment for the refrigerant R22

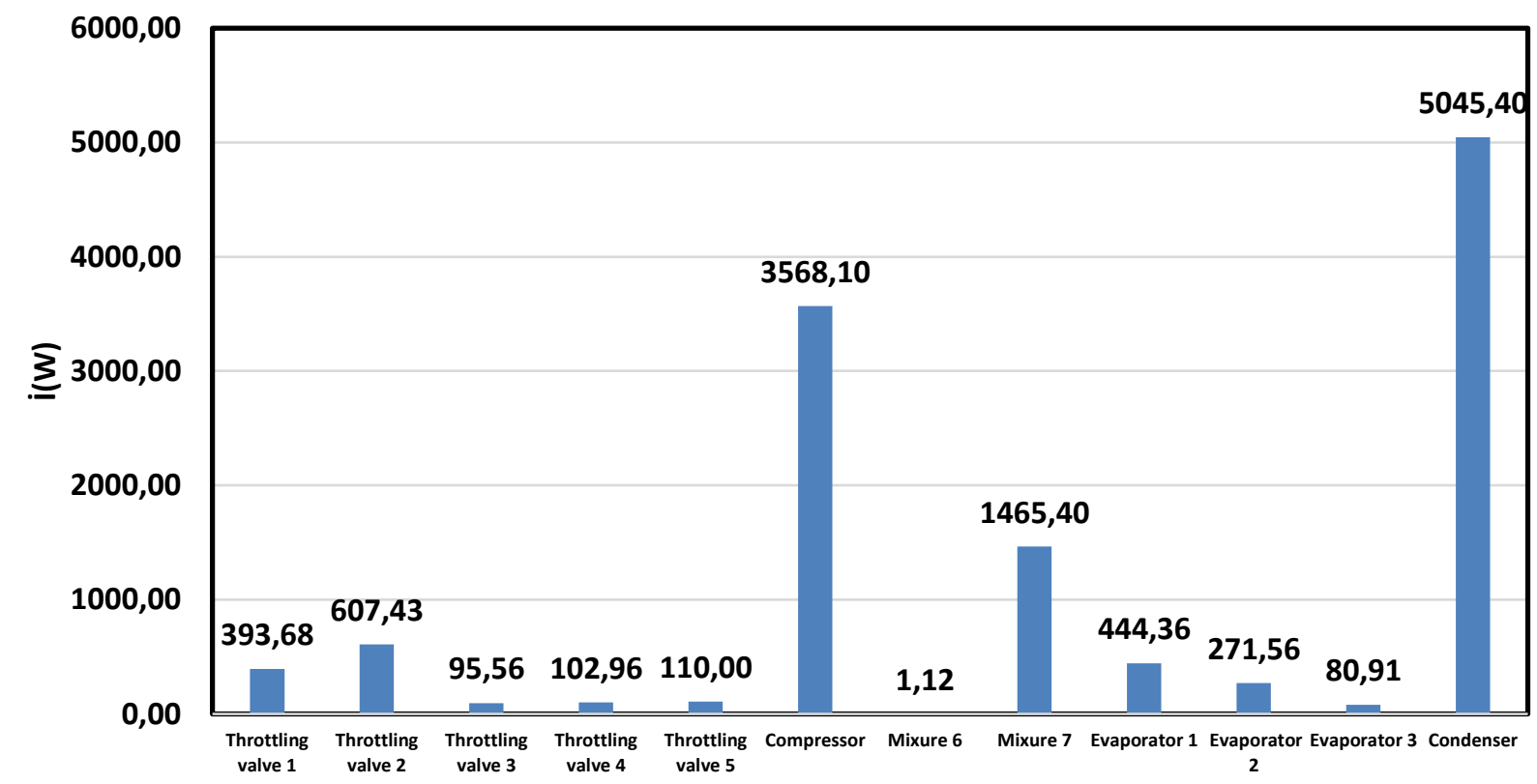

Figure 9. The exergy loss in different components of the VRF equipment for the refrigerant R134a

The dual-purpose genetic algorithm is used for optimization of the system. Table 6 shows the specifications of the dual-purpose genetic algorithm used in the current study. 
Table 6. The specifications of the genetic algorithm

\begin{tabular}{|c|c|}
\hline Parameters & Value \\
\hline Population & 100 \\
\hline Initial range & {$[-10,10]$} \\
\hline Time limits & $\infty$ \\
\hline Cross over fraction & 0.6 \\
\hline Function tolerance & $10^{-5}$ \\
\hline Constraint & $10^{-4}$ \\
\hline
\end{tabular}

The objective functions of the optimization are $\mathrm{C}_{\mathrm{Q}}\left(\frac{U S \$}{k W h}\right)$ (the cost of produced cooling and $\eta_{\Pi}$ (efficiency of the second law of thermodynamics). The variables considered for the optimization are as follows:

$$
\begin{gathered}
0.07<\dot{\mathrm{m}}_{4}<0.1(\mathrm{~kg} / \mathrm{s}) \\
0.07<\dot{\mathrm{m}}_{7}<0.1(\mathrm{~kg} / \mathrm{s}) \\
\dot{\mathrm{m}}_{1}=0.23156(\mathrm{~kg} / \mathrm{s})
\end{gathered}
$$

$$
\begin{array}{r}
2300<\mathrm{P}_{2}<2500(\mathrm{kPa}) \\
900<\mathrm{P}_{4}<1100(\mathrm{kPa} \\
700<\mathrm{P}_{7}<800(\mathrm{kPa})
\end{array}
$$

Figure 10 shows the Pareto graph of the VRF cycle for the refrigerant R11. By the change in cycle's exergy efficiency from 10 to 16 , the cost of the cooling is decreased from $0.233\left(\frac{U S \$}{k W h}\right)$ to $0.205\left(\frac{U S \$}{k W h}\right)$. The optimized values of the variables are shown in table 7. Figure 11 shows the changes in the efficiency of the second law of thermodynamics for the VRF cycle per mass discharge of evaporator 1, for the refrigerant R11. By the increase in evaporator 1's mass discharge from 0.07 to $0.1(\mathrm{~kg} / \mathrm{s})$, the cycle's exergy is decreased from 14.1 to $13.9 \%$.

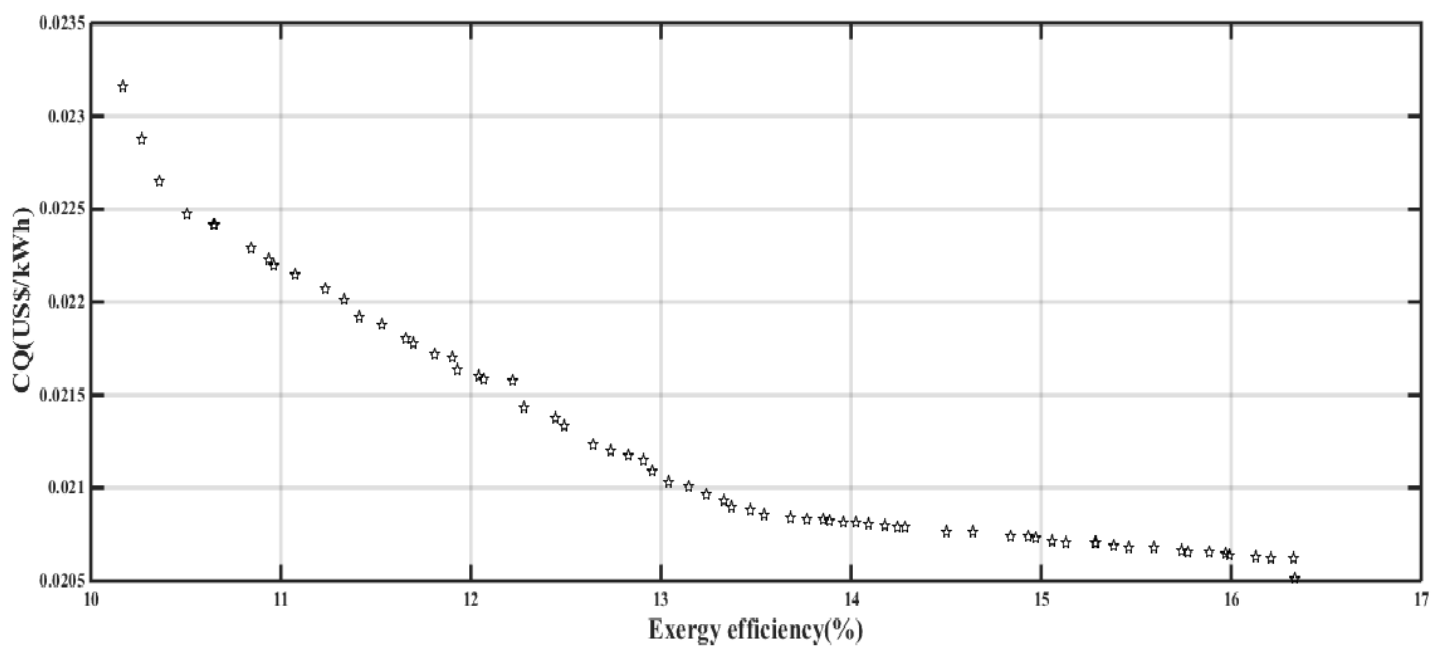

Figure 10. Pareto graph of VRF cycle for R11

Table 7. The optimal values of the VRF cycle variables for R11

\begin{tabular}{|c|c|}
\hline$\dot{\mathrm{m}}_{4}(\mathrm{~kg} / \mathrm{s})$ & 0.0712 \\
\hline$\dot{\mathrm{m}}_{7}(\mathrm{~kg} / \mathrm{s})$ & 0.0989 \\
\hline $\mathrm{P}_{2}(\mathrm{kPa})$ & 2813 \\
\hline $\mathrm{P}_{4}(\mathrm{kPa})$ & 916.9 \\
\hline $\mathrm{P}_{7}(\mathrm{kPa})$ & 722.5 \\
\hline $\mathrm{P}_{10}(\mathrm{kPa})$ & 800 \\
\hline
\end{tabular}




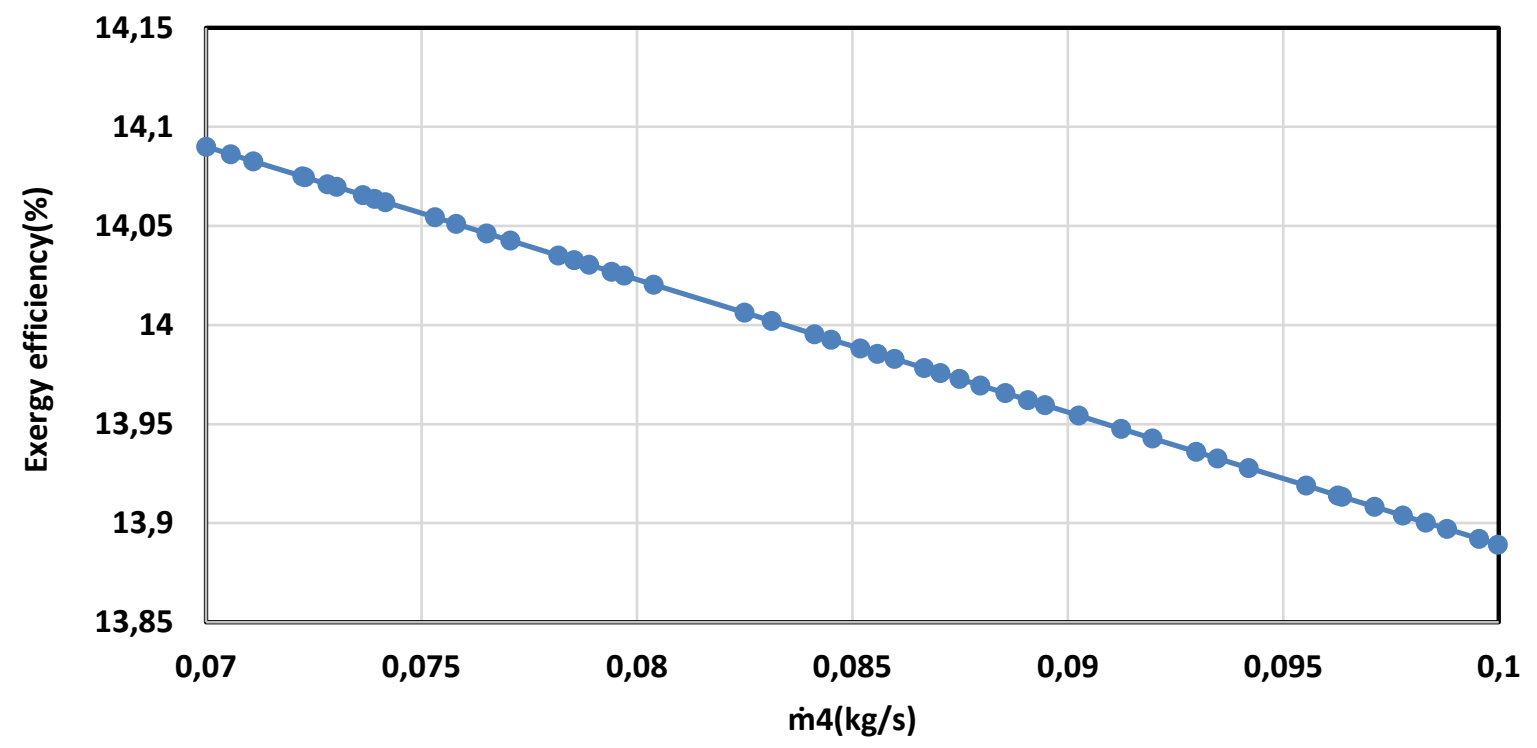

Figure 11. The changes in efficiency of the second law of thermodynamics for the VRF cycle per mass discharge of evaporator 1 , for the refrigerant R11

Figure 12 shows the changes in $\mathrm{COP}$ of the system per condenser pressure for refrigerant R11. The COP changes of the cycle is descending with the increase in condenser pressure. Figure 13 shows the changes in the efficiency of the second law of thermodynamics for the VRF system per evaporator 1's pressure. By the increase in evaporator 1's pressure from $900(\mathrm{kPa})$ to $1100(\mathrm{kPa})$, the efficiency of the second law of thermodynamics for the VRF cycle is decreased from 16.4 to $15.6 \%$. Therefore, it can be concluded that the changes in evaporator 1's pressure have no significant effects on the efficiency of the second law of thermodynamics for the VRF system.

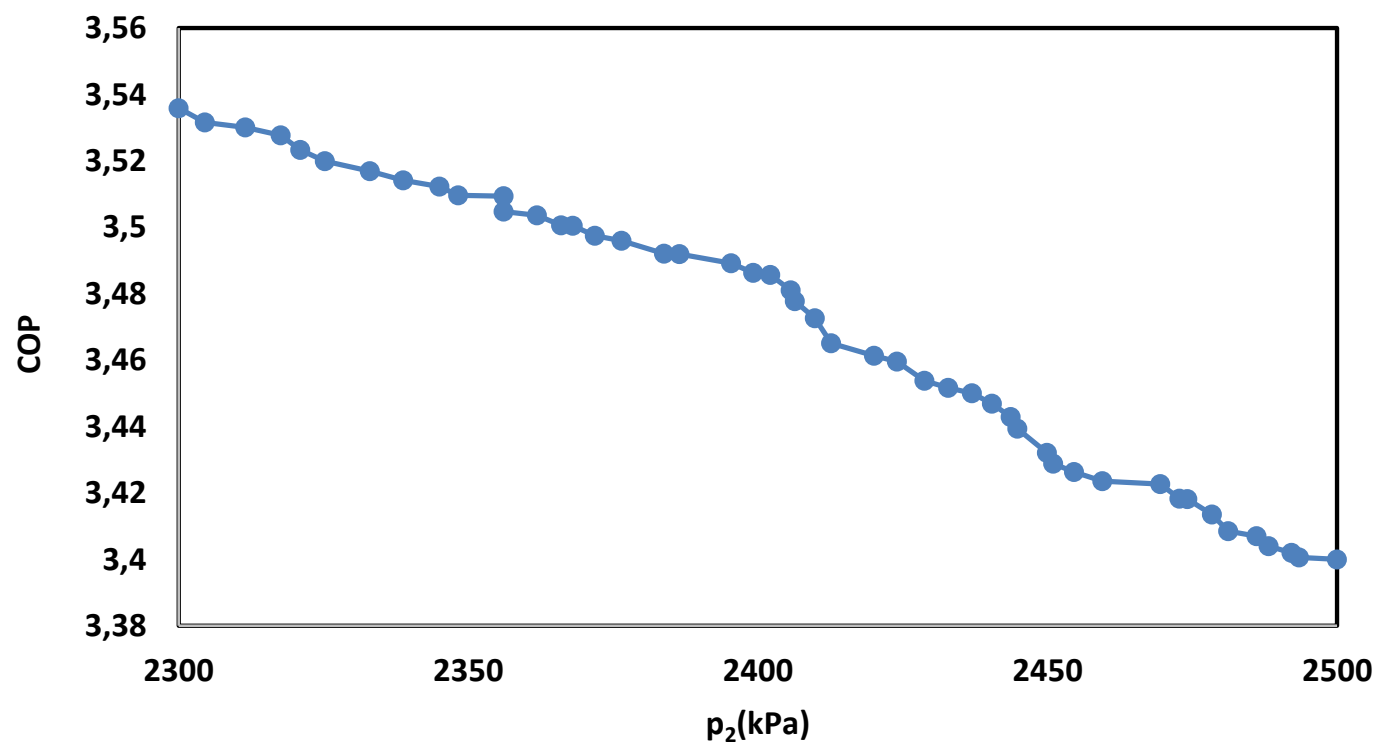

Figure 12. The changes in $\mathrm{COP}$ of the system per condenser pressure for refrigerant $\mathrm{R} 11$ 


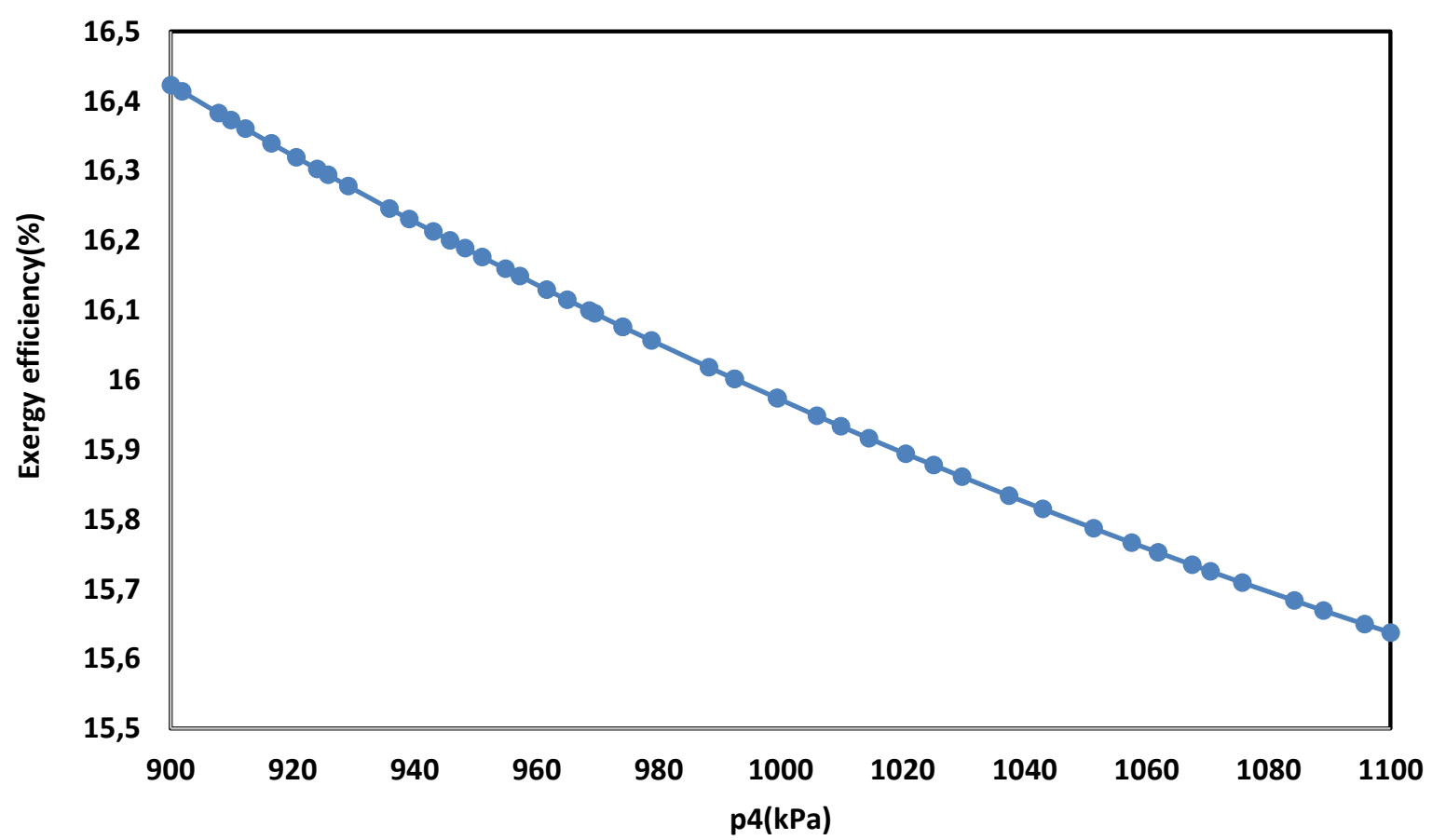

Figure 13. The changes in efficiency of the second law of thermodynamics for the VRF system per evaporator 1's

$$
\text { pressure }
$$

Figure 14 shows the Pareto graph of the refrigerant R22 and VRF equipment. The trend of the changes is similar to that of R11, i.e., by the increase in efficiency of the second law of thermodynamics, the cooling costs of the VRF equipment are decreased. However, it should be noted that the values of the second law of thermodynamics and cooling costs for the R22 refrigerant are different from those of R11. By the increase in efficiency of the second law of thermodynamics from 13 to $29 \%$, the cost of the cooling produced by the VRF is decreased from $0.0188\left(\frac{U S \$}{k W h}\right)$ to $0.0168\left(\frac{U S \$}{k W h}\right)$. Table 8 shows the optimal values VRF equipment variables for the refrigerant R22.

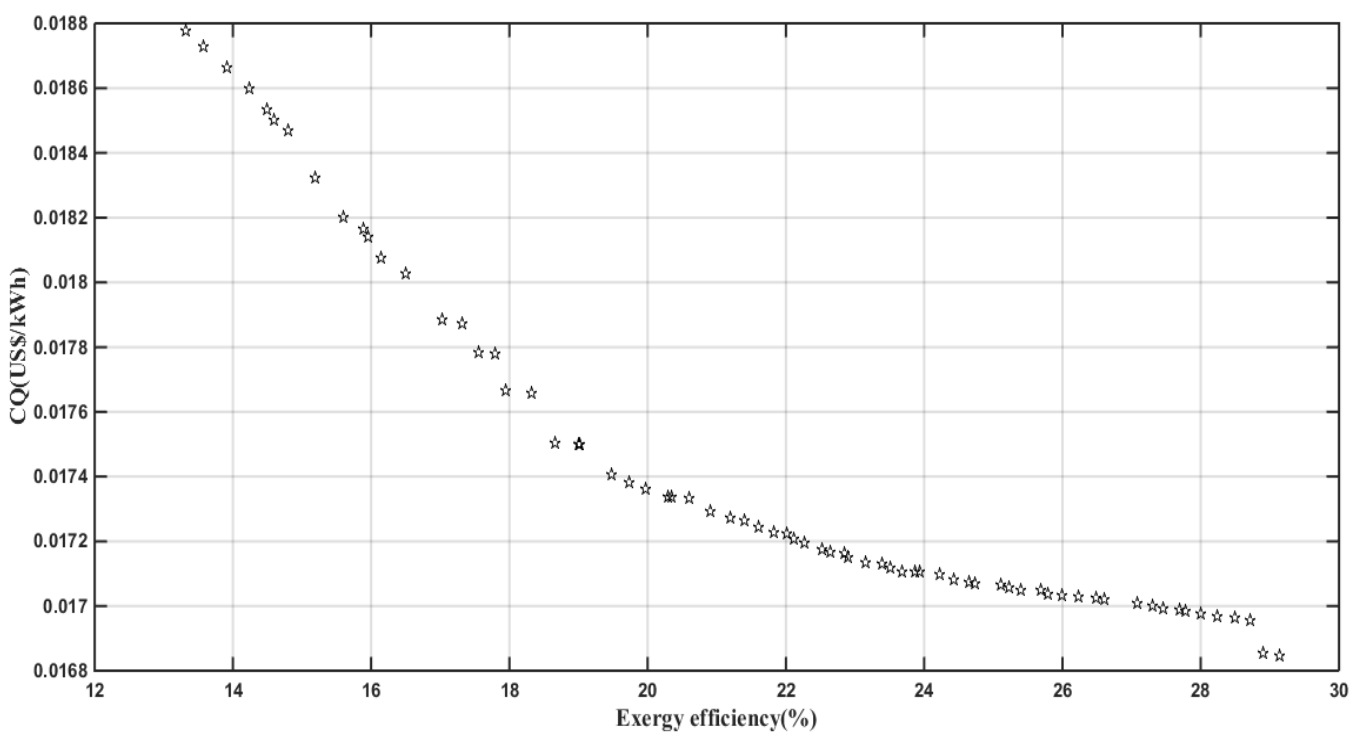

Figure 14. Pareto graph of the refrigerant R22 and VRF equipment 
Table 8. The optimal values VRF equipment variables for the refrigerant R22

\begin{tabular}{|c|c|}
\hline$\dot{\mathrm{m}}_{4}(\mathrm{~kg} / \mathrm{s})$ & 0.072 \\
\hline$\dot{\mathrm{m}}_{7}(\mathrm{~kg} / \mathrm{s})$ & 0.099 \\
\hline $\mathrm{P}_{2}(\mathrm{kPa})$ & 2307.3 \\
\hline $\mathrm{P}_{4}(\mathrm{kPa})$ & 926.84 \\
\hline $\mathrm{P}_{7}(\mathrm{kPa})$ & 717.06 \\
\hline $\mathrm{P}_{10}(\mathrm{kPa})$ & 799.7 \\
\hline
\end{tabular}

If the values of table 8 are compared with those of table 7 , it can be concluded that the optimal values are almost in the same range with no significant difference. Therefore, changing the refrigerant R11 to R22 has no significant effects on the optimal values of the cycle. Figure 15 shows the changes in the efficiency of the second law of thermodynamics for VRF equipment per mass discharge of the evaporator 1's refrigerant, for R22. It can be seen in the figure that by the increase in the mass discharge of evaporator 1 from 0.07 to $0.1 \mathrm{~kg} / \mathrm{s}$, the efficiency of the second law of thermodynamics is decreased from 29.2 to $28 \%$. Through comparison of the above figure with figure 11 , it can be known that the trends of the changes in the efficiency of the second law of thermodynamics for the VRF equipment, or mass discharge of evaporator 1, are similar for the refrigerants R11 and R22, i.e., for both refrigerants, the trend is descending.

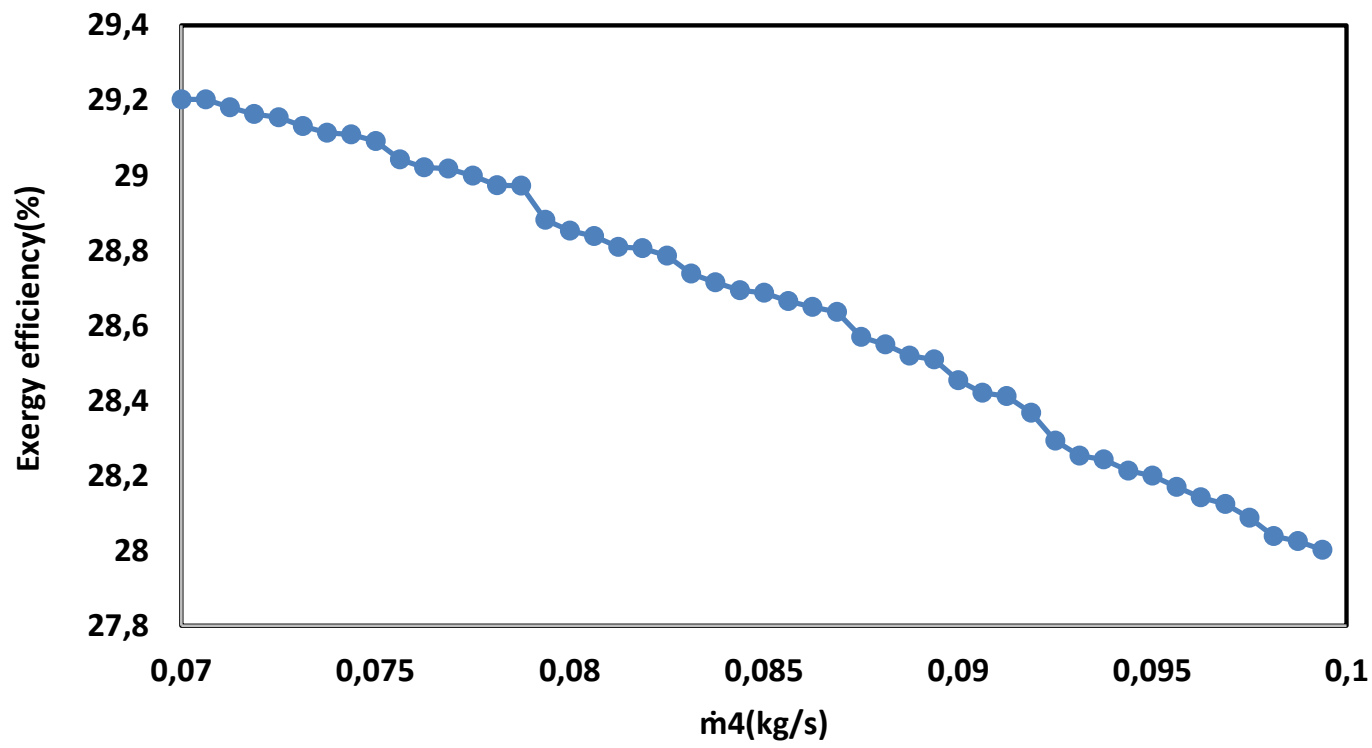

Figure 15. The changes in the efficiency of the second law of thermodynamics for VRF equipment per mass discharge of the evaporator 1's refrigerant, for R22

Figure 16 shows the changes in COP per condenser pressure for the refrigerant R22. The trend of the changes is similar to that of figure 12. Figure 17 shows the changes in the efficiency of the second law of thermodynamics for refrigerant R22 per evaporator 1's pressure. By changing the evaporator's pressure from $900(\mathrm{kPa})$ to $1100(\mathrm{kPa})$, the efficiency of the second law of thermodynamics is decreased from 29.7 to $25.9 \%$. Figure 18 shows the costs of the cooling produced by the VRF system per evaporator 1's pressure, for refrigerant R22. The increase in pressure from $900(\mathrm{kPa})$ to $1100(\mathrm{kPa})$, leads to the increase in the cooling costs from $0.0169\left(\frac{U S \$}{\mathrm{kWh}}\right)$.to $0.0172\left(\frac{U S \$}{\mathrm{kWh}}\right)$. Figure 19 shows the Pareto graph of R134a and VRF equipment. By the increase in efficiency of the second law of thermodynamics from 18 to $34 \%$, the cost of cooling is decreased from 0.0186 to $0.0166\left(\frac{U S \$}{k W h}\right)$. Table 9 shows the 
Journal of Thermal Engineering, Research Article, Vol. 6, No. 3, pp. 381-404, April, 2020

optimal values of the VRF cycle with R134a refrigerant. Comparing the table 9 with tables 7 and 8 , it can found out that changing the refrigerant from R11 to R22 and R134a does not significantly affect the optimal values of the cycle.

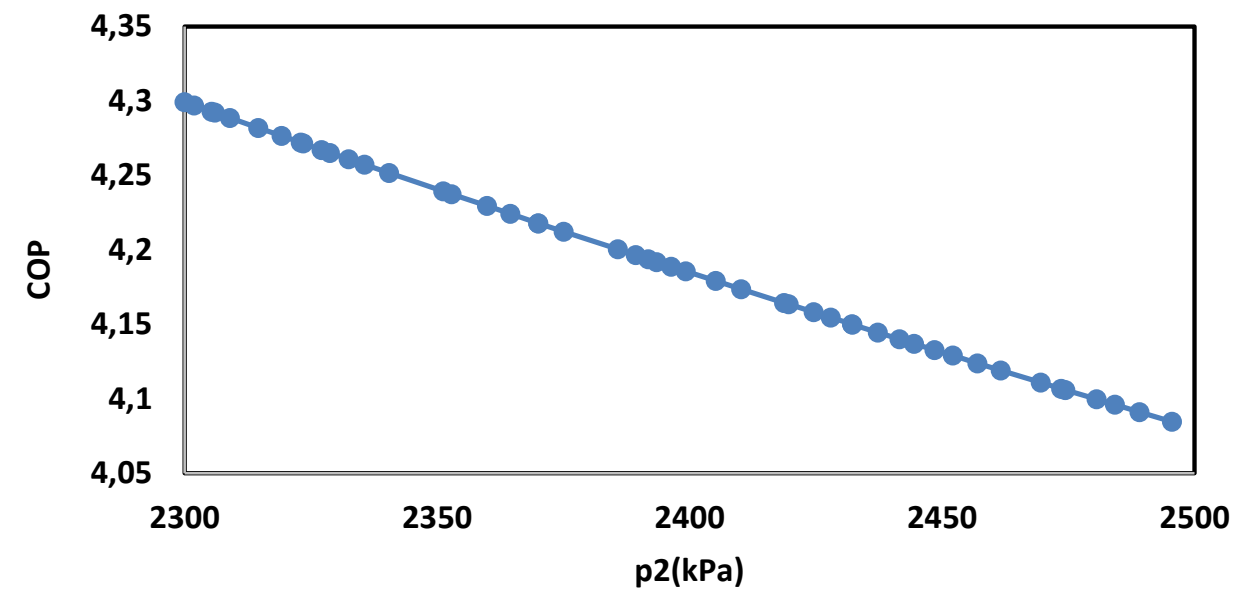

Figure 16. The changes in COP per condenser pressure for the refrigerant $\mathrm{R} 22$

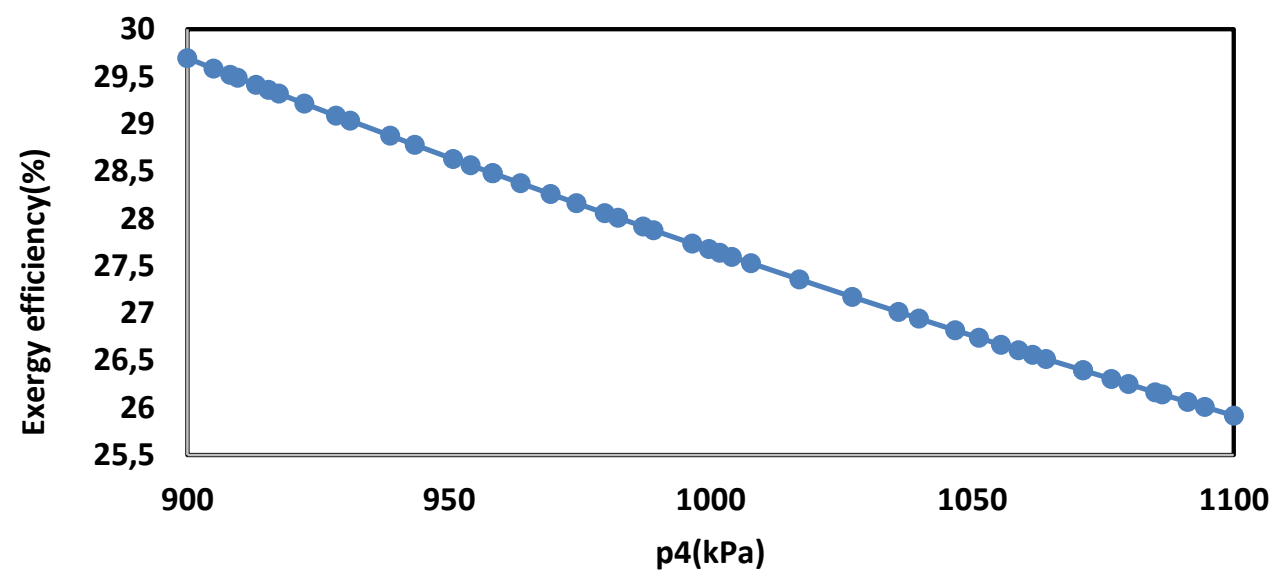

Figure 17. The changes in efficiency of the second law of thermodynamics for refrigerant R22 per evaporator 1's pressure

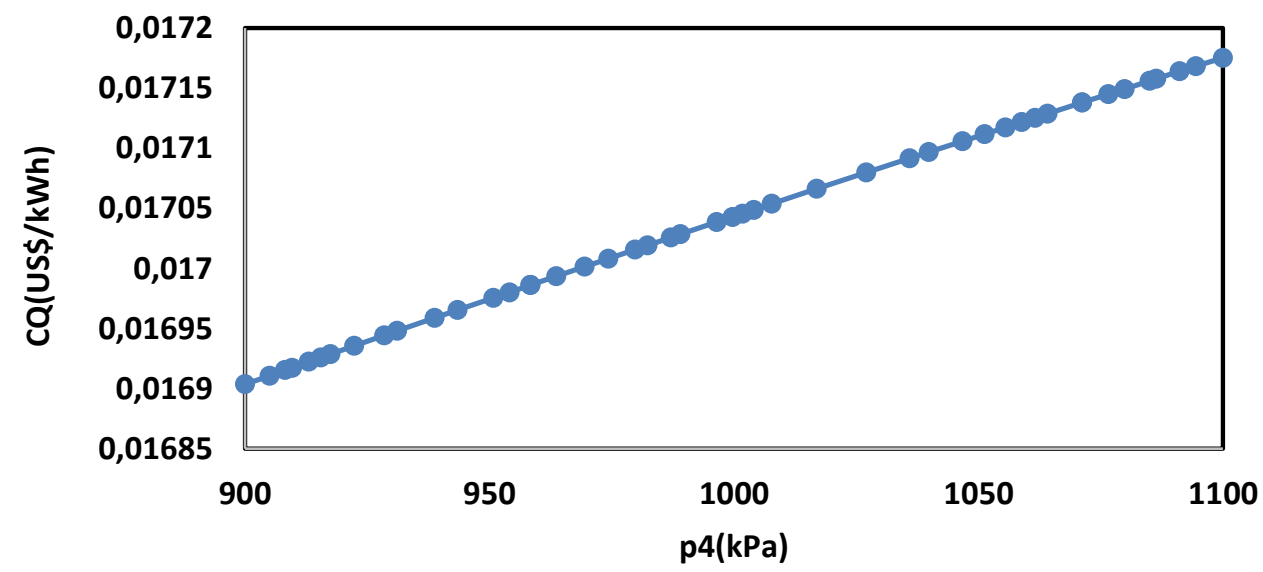

Figure 18. The costs of the cooling produced by the VRF system per evaporator 1's pressure, for refrigerant R22 


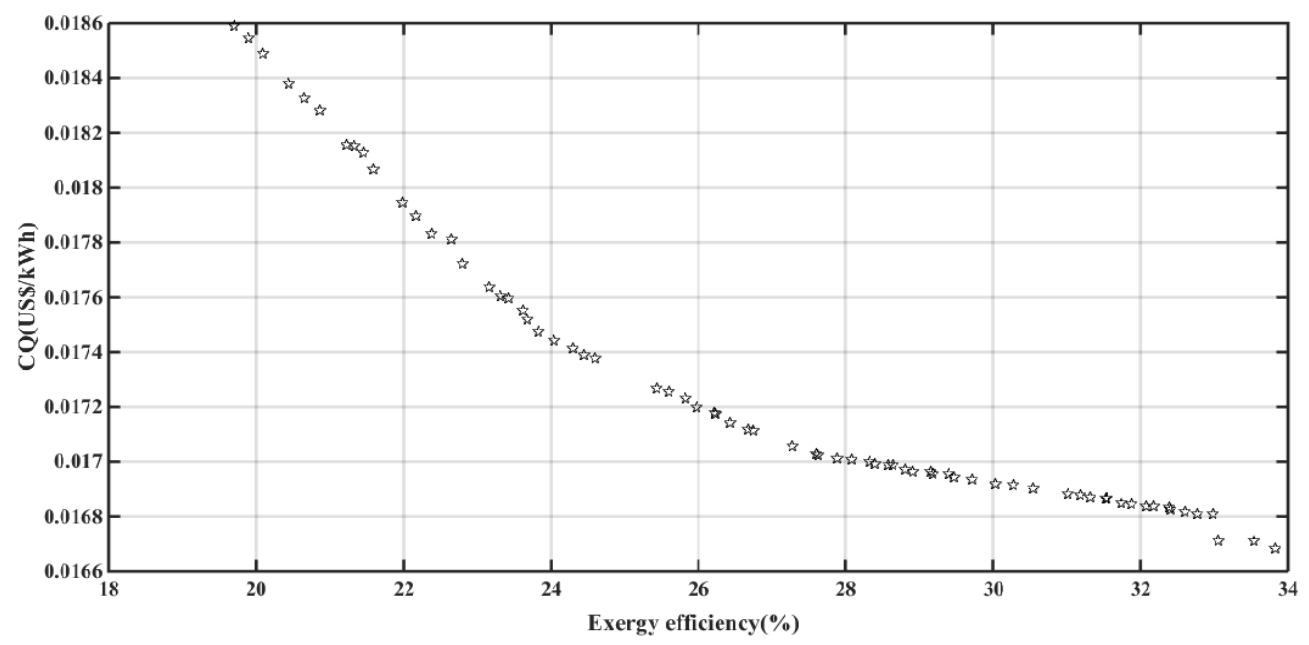

Figure 19. Pareto graph of R134a and VRF equipment

Table 9. The optimal values of the VRF cycle with R134a refrigerant

\begin{tabular}{|c|c|}
\hline$\dot{\mathrm{m}}_{4}(\mathrm{~kg} / \mathrm{s})$ & 0.072 \\
\hline$\dot{\mathrm{m}}_{7}(\mathrm{~kg} / \mathrm{s})$ & 0.1 \\
\hline $\mathrm{P}_{2}(\mathrm{kPa})$ & 2312.2 \\
\hline $\mathrm{P}_{4}(\mathrm{kPa})$ & 925.8 \\
\hline $\mathrm{P}_{7}(\mathrm{kPa})$ & 706.2 \\
\hline $\mathrm{P}_{10}(\mathrm{kPa})$ & 799.7 \\
\hline
\end{tabular}

Figure 20 shows the changes in the efficiency of the second law of thermodynamics for VRF cycle per condenser pressure for R134a. By the change in condenser pressure from 2300 to $2500(\mathrm{kPa})$, the exergy efficiency is increased from 3.8 to $4.4 \%$. It should be noted that the condenser pressure for the refrigerant R134a does not significantly affect the efficiency of the second law of thermodynamic for VRF cycle. Figure 21 shows the effects of the condenser pressure on the cost of cooling produced by VRF cycle, for the refrigerant R134a. By the increase in condenser pressure, the cost of the cooling has an ascending trend.

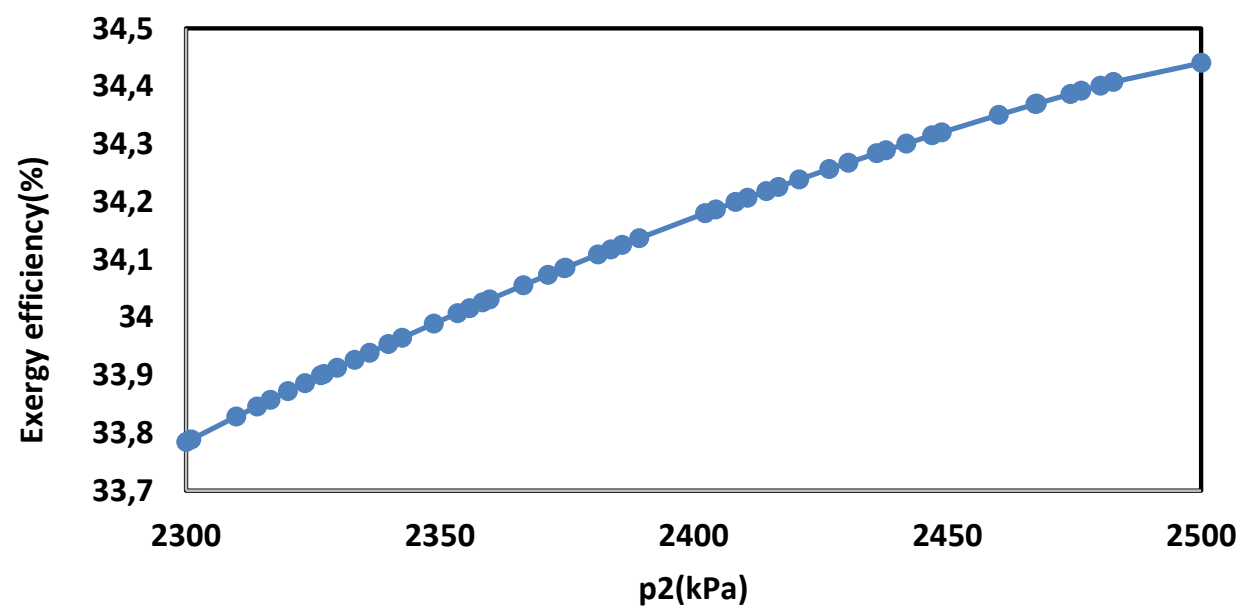

Figure 20. The changes in efficiency of the second law of thermodynamics for VRF cycle per condenser pressure for R134a 


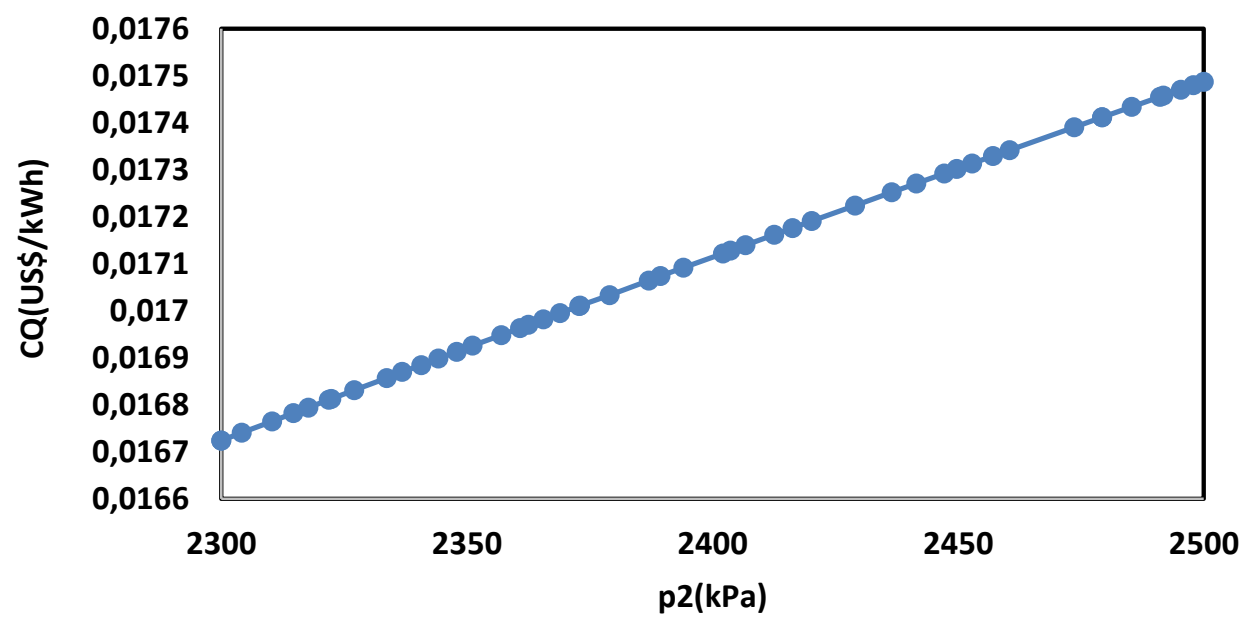

Figure 21. The effects of the condenser pressure on the cost of cooling produced by VRF cycle, for the refrigerant

\section{CONCLUSION}

R134a

The current study aimed at energy, exergy, and economic analysis of the VRF cycle. This VRF cycle has 3 evaporators, 2 mixers, 5 expansion valves, one compressor, and one condenser. The three refrigerants R11, R22, and R134a were considered. The multi-purpose genetic algorithm was used for optimization of this system. The objective functions were cooling costs and second law efficiency. The variables considered for the optimization were condenser and evaporators 1,2 , and 3 pressure, mass discharge of the evaporators 1 and 2, and the mass discharge of the condenser, respectively. The results of the current study are as follows:

-The highest COP and efficiency of second law of thermodynamics is for the R134a, and second and third to it are R22 and R11.

-The lowest exergy loss and cooling costs belonged is for the R134a, with R22 and R11 being second and third.

-The change in the refrigerant type does not significantly affect the optimal values obtained by the dual-purpose genetic algorithm.

-The sensitivity analysis shows that by the increase in the mass discharge of refrigerant inside the evaporator, the efficiency of the second law of thermodynamics of the VRF cycle for all the three refrigerants is reduced.

\section{NOMENCLATURE:}

A

$\mathrm{C}\left(\frac{\mathrm{US} \$}{\mathrm{kWh}}\right)$

COP

$\mathrm{g}\left(\frac{\mathrm{m}}{\mathrm{s}^{2}}\right)$

$\mathrm{h}\left(\frac{\mathrm{kJ}}{\mathrm{kg}}\right)$

I

$\dot{\mathrm{I}}(\mathrm{kW})$

$\mathrm{K}$

L

$\dot{\mathrm{m}}\left(\frac{\mathrm{kg}}{\mathrm{s}}\right)$

$\mathrm{P}(\mathrm{kW})$

$\dot{\mathrm{Q}}(\mathrm{kW})$

$\mathrm{T}(\mathrm{K})$

$\mathrm{V}\left(\frac{\mathrm{m}}{\mathrm{s}}\right)$

$\dot{\mathrm{W}}(\mathrm{kW})$

$\mathrm{z}(\mathrm{m})$

\section{Coefficient}

Cost

Coefficient of performance

Gravity

Enthalpy

Interest rate

Irrerorsibility

Coefficient

Equipment life

Mass flow rate

Power of electric motor

Heat transfer rate

Temperature

Speed

Power

Height 
Greek symbols

$\Psi\left(\frac{\mathrm{kJ}}{\mathrm{kg}}\right) \quad$ Exergy

Subscripts

$\begin{array}{ll}1,2,3,4,5,6,7,8,9,10,11,12,13,14 & \begin{array}{l}\text { Number in Figure (1) } \\ \text { Compressor }\end{array} \\ \text { Comp } & \text { Condenser } \\ \text { Cond } & \text { Control volume } \\ \text { CV } & \text { Standard condition } \\ 0 & \text { Exit } \\ \text { E } & \text { Electrical } \\ \text { Elec } & \text { Evaporators 1,2,3 } \\ \text { Evap 1,2,3 } & \text { Expansion valve } \\ \text { Exp } & \text { Exit } \\ \text { E } & \text { Intel } \\ \text { I } & \text { Initial } \\ \text { I } & \text { Operation and maintenance } \\ \text { O } & \text { Cooling } \\ \text { Q } & \text { Separator } \\ \text { Sep } & \end{array}$

\section{REFERENCES}

[1] Ebadati M, Ehyaei MA. Reduction of energy consumption in residential buildings with green roofs in three different climates of Iran. Advances in Building Energy Research. 2020;14(1):66-93 10.1080/17512549.2018.1489894.

[2] Li ZX, Ehyaei MA, Kamran Kasmaei H, Ahmadi A, Costa V. Thermodynamic modeling of a novel solar powered quad generation system to meet electrical and thermal loads of residential building and syngas production. Energy Conversion and Management. 2019;199:111982 doi.org/10.1016/j.enconman.2019.

[3] Aynur TN. Variable refrigerant flow systems: A review. Energy and Buildings. 2010;42(7):1106-12 doi.org/10.016/j.enbuild.2010.01.024.

[4] Kwon L, Lee H, Hwang Y, Radermacher R, Kim B. Experimental investigation of multifunctional VRF system in heating and shoulder seasons. Applied Thermal Engineering. 2014;66(1-2):355-64 doi.org/10.1016/j.applthermaleng.2014.02.032.

[5] Zhu Y, Jin X, Du Z, Fan B, Fang X. Simulation of variable refrigerant flow air conditioning system in heating mode combined with outdoor air processing unit. Energy and Buildings. 2014;68:571-9 doi.org/10.1016/j.enbuild.2013.09.042.

[6] Meng J, Liu M, Zhang W, Cao R, Li Y, Zhang H, et al. Experimental investigation on cooling performance of multisplit variable refrigerant flow system with microchannel condenser under part load conditions. Applied Thermal Engineering. 2015;81:232-41 doi.org/10.1016/j.applthermaleng.2015.02.007.

[7] Yu X, Yan D, Sun K, Hong T, Zhu D. Comparative study of the cooling energy performance of variable refrigerant flow systems and variable air volume systems in office buildings. Applied energy. 2016;183:725-36 doi.org/10.1016/j.apenergy.2016.09.033.

[8] Kim D, Cox SJ, Cho H, Im P. Model calibration of a variable refrigerant flow system with a dedicated outdoor air system: A case study. Energy and Buildings. 2018;158:884-96 doi.org/10.1016/j.enbuild.2017.10.049.

[9] Kani-Sanchez C, Richman R. Incorporating variable refrigerant flow (VRF) heat pump systems in whole building energy simulation-Detailed case study using measured data. Journal of Building Engineering. 2017;12:314-24 doi.org/10.1016/j.jobe.2017.06.016.

[10] Li Z, Wang B, Li X, Shi W, Zhang S, Liu Y. Simulation of recombined household multi-split variable refrigerant flow system with split-type air conditioners. Applied Thermal Engineering. 2017;117:343-54 doi.org/10.1016/j.applthermaleng.2017.02.003.

[11] Koury R, Machado L, Ismail K. Numerical simulation of a variable speed refrigeration system. International journal of refrigeration. 2001;24(2):192-200 doi.org/10.1016/S0140-7007(00)00014-1. 
[12] Winkler J, Aute V, Radermacher R. Comprehensive investigation of numerical methods in simulating a steadystate vapor compression system. International Journal of Refrigeration. 2008;31(5):930-42 doi.org/10.1016/j.ijrefrig.2007.08.008.

[13] Meissner JW, Abadie MO, Moura LM, Mendonça KC, Mendes N. Performance curves of room air conditioners for building energy simulation tools. Applied energy. 2014;129:243-52 doi.org/10.1016/j.apenergy.2014.04.094.

[14] Aliehyaei MA. OPTIMIZATION OF MICRO GAS TURBINE BY ECONOMIC, EXERGY AND ENVIRONMENT ANALYSIS USING GENETIC, BEE COLONY AND SEARCHING ALGORITHMS. Journal of Thermal Engineering. 2020;6(1):117-40 10.18186/thermal.672054.

[15] Yousefi M, Ehyaei MA, Rosen MA. Optimizing a New Configuration of a Proton Exchange Membrane Fuel Cell Cycle With Burner and Reformer Through a Particle Swarm Optimization Algorithm for Residential Applications. Journal of Electrochemical Energy Conversion and Storage. 2019;16(4):1-12 DOI:0.1115/1.4044812.

[16] Rajaei G, Atabi F, Ehyaei M. Feasibility of using biogas in a micro turbine for supplying heating, cooling and electricity for a small rural building. Advances in Energy Research. 2017;5(2):129-42 10.12989/eri.2017.5.2.000.

[17] Shamoushaki M, Ehyaei MA. Exergy, economic and environmental (3E) analysis of a gas turbine power plant and optimization by MOPSO algorithm. Thermal Science. 2018;22(6 Part A):2641-51 10.298/TSCI161011091S.

[18] Chegini S, Ehyaei MA. Economic, exergy, and the environmental analysis of the use of internal combustion engines in parallel-to-network mode for office buildings. Journal of the Brazilian Society of Mechanical Sciences and Engineering. 2018;40(9):433 10.1007/s40430-018-1349-4.

[19] Shaygan M, Ehyaei MA, Ahmadi A, Assad MEH, Silveira JL. Energy, exergy, advanced exergy and economic analyses of hybrid polymer electrolyte membrane (PEM) fuel cell and photovoltaic cells to produce hydrogen and electricity. Journal of Cleaner Production. 2019;234:1082-93 doi.org/10.16/j.jclepro.2019.06.298.

[20] Mozafari A, Ehyaei MA. Effects of Regeneration Heat Exchanger on Entropy, Electricity Cost, and Environmental Pollution Produced by Micro Gas Turbine System. International Journal of Green Energy. 2012;9(1):51-70 10.1080/15435075.2011.617021.

[21] Farshin B, Ehyaei M. Optimization of photovoltaic thermal (PV/T) hybrid collectors by genetic algorithm in Iran. Advances in Energy Research. 2017;5(1):31 http://dx.doi.org/10.12989/eri.2017.5.1.031 31.

[22] Yousefi M, Ehyaei MA. Feasibility study of using organic Rankine and reciprocating engine systems for supplying demand loads of a residential building. Advances in Building Energy Research. 2019;13(1):32-48 10.1080/17512549.2017.1354779.

[23] Ehyaei MA, Bahadori MN. Internalizing the Social Cost of Noise Pollution in the Cost Analysis of Electricity Generated by Wind Turbines. Wind Engineering. 2006;30(6):521-9 10.1260/030952406779994114.

[24] Shamoushaki M, Ghanatir F, Ehyaei M, Ahmadi A. Exergy and exergoeconomic analysis and multi-objective optimisation of gas turbine power plant by evolutionary algorithms. Case study: Aliabad Katoul power plant. International Journal of Exergy. 2017;22(3):279-307 10.1504/IJEX.2017.083160.

[25] Ehyaei MA, Ahmadi A, Rosen MA. Energy, exergy, economic and advanced and extended exergy analyses of a wind turbine. Energy Conversion and Management. 2019;183:369-81 doi.org/10.1016/j.enconman.2019.01.008.

[26] Ghasemian E, Ehyaei MA. Evaluation and optimization of organic Rankine cycle (ORC) with algorithms NSGAII, MOPSO, and MOEA for eight coolant fluids. International Journal of Energy and Environmental Engineering. 2018;9(1):39-57 10.1007/s40095-017-0251-7.

[27] Asgari E, Ehyaei M. Exergy analysis and optimisation of a wind turbine using genetic and searching algorithms. International Journal of Exergy. 2015;16(3):293-314 10.1504/IJEX.2015.068228.

[28] Yazdi MRM, Aliehyaei M, Rosen MA. Exergy, economic and environmental analyses of gas turbine inlet air cooling with a heat pump using a novel system configuration. Sustainability. 2015;7(10):14259-86 $10.3390 /$ su71014259.

[29] Ehyaei MA, Rosen MA. Optimization of a triple cycle based on a solid oxide fuel cell and gas and steam cycles with a multiobjective genetic algorithm and energy, exergy and economic analyses. Energy Conversion and Management. 2019;180:689-708 10.1016/j.enconman.2018.11.023.

[30] Bejan A. Advanced engineering thermodynamics: John Wiley \& Sons, 2016.

[31] Horngren CT, Foster G, Datar SM, Rajan M, Ittner C, Baldwin AA. Cost accounting: A managerial emphasis. Issues in Accounting Education. 2010;25(4):789-90.

[32] Ehyaei MA, Mozafari A. Energy, economic and environmental (3E) analysis of a micro gas turbine employed for on-site combined heat and power production. Energy and Buildings. 2010;42(2):259-64 doi.org/10.1016/j.enbuild.2009.09.001.

[33] Ehyaei MA, Ahmadi P, Atabi F, Heibati MR, Khorshidvand M. Feasibility study of applying internal combustion engines in residential buildings by exergy, economic and environmental analysis. Energy and Buildings. 2012;55:40513 doi.org/10.1016/j.enbuild.2012.09.002. 
Journal of Thermal Engineering, Research Article, Vol. 6, No. 3, pp. 381-404, April, 2020

[34] El-Sayed Y, Tribus M. A specific strategy for the improvement of process economics. Center for Advanced Engineering Study, MIT, Cambridge, MA, USA. 1982.

[35] Eiben AE, Raue P-E, Ruttkay Z. Genetic algorithms with multi-parent recombination. Conference Genetic algorithms with multi-parent recombination. Springer, p. 78-87. 